\title{
The IMAGEN study: a decade of imaging genetics in adolescents
}

\author{
Lea Mascarell Maričić ${ }^{1} \cdot$ Henrik Walter (10) ${ }^{1}$ Annika Rosenthal ${ }^{1} \cdot$ Stephan Ripke ${ }^{1}$ Erin Burke Quinlan (i) ${ }^{2}$. \\ Tobias Banaschewski $\mathbb{D}^{3}$. Gareth J. Barker $\mathbb{C}^{4} \cdot$ Arun L. W. Bokde ${ }^{5}$. Uli Bromberg $\mathbb{D}^{6} \cdot$ Christian Büchel $^{7}$. \\ Sylvane Desrivières $\mathbb{D}^{2} \cdot$ Herta Flor ${ }^{7,8} \cdot$ Vincent Frouin $\mathbb{D}^{9} \cdot$ Hugh Garavan $^{10} \cdot$ Bernd Itterman $^{11}$. \\ Jean-Luc Martinot $\mathbb{D}^{12} \cdot$ Marie-Laure Paillère Martinot ${ }^{13} \cdot$ Frauke Nees $^{3,7} \cdot$ Dimitri Papadopoulos Orfanos $\left(\mathbb{D}^{9} \cdot\right.$ \\ Tomáš Paus $^{14} \cdot$ Luise Poustka $^{15}$. Sarah Hohmann ${ }^{3}$ - Michael N. Smolka $\mathbb{D}^{16}$ • Juliane H. Fröhner $\mathbb{D}^{16}$. \\ Robert Whelan $\mathbb{D}^{17} \cdot$ Jakob Kaminski $\mathbb{D}^{1,18} \cdot$ Gunter Schumann $\mathbb{D}^{2} \cdot$ Andreas Heinz ${ }^{1} \cdot$ IMAGEN consortium
}

Received: 5 May 2019 / Revised: 10 April 2020 / Accepted: 12 June 2020 / Published online: 29 June 2020

(c) The Author(s) 2020. This article is published with open access

\begin{abstract}
Imaging genetics offers the possibility of detecting associations between genotype and brain structure as well as function, with effect sizes potentially exceeding correlations between genotype and behavior. However, study results are often limited due to small sample sizes and methodological differences, thus reducing the reliability of findings. The IMAGEN cohort with 2000 young adolescents assessed from the age of 14 onwards tries to eliminate some of these limitations by offering a longitudinal approach and sufficient sample size for analyzing gene-environment interactions on brain structure and function. Here, we give a systematic review of IMAGEN publications since the start of the consortium. We then focus on the specific phenotype 'drug use' to illustrate the potential of the IMAGEN approach. We describe findings with respect to frontocortical, limbic and striatal brain volume, functional activation elicited by reward anticipation, behavioral inhibition, and affective faces, and their respective associations with drug intake. In addition to describing its strengths, we also discuss limitations of the IMAGEN study. Because of the longitudinal design and related attrition, analyses are underpowered for (epi-) genome-wide approaches due to the limited sample size. Estimating the generalizability of results requires replications in independent samples. However, such densely phenotyped longitudinal studies are still rare and alternative internal crossvalidation methods (e.g., leave-one out, split-half) are also warranted. In conclusion, the IMAGEN cohort is a unique, very well characterized longitudinal sample, which helped to elucidate neurobiological mechanisms involved in complex behavior and offers the possibility to further disentangle genotype $\times$ phenotype interactions.
\end{abstract}

\section{Introduction}

Two decades ago, several groups started to associate genetic variants with measures of brain structure and function rather than clinically diagnosed disease categories [1-4]. For example, it was assumed that variance in the genetic constitution of monoamine transporters should have a stronger

These authors contributed equally: Lea Mascarell Maričić, Henrik Walter, Gunter Schumann, Andreas Heinz

Members of the IMAGEN consortium are listed below Acknowledgements.

Andreas Heinz

andreas.heinz@charite.de

Extended author information available on the last page of the article impact on in vivo transporter availability and, consequently, brain function than on subjective mood states [1,2]. Likewise, genetic variants associated with the dopamine D2 receptor were associated with in vivo receptor availability $[3,5]$. Shortly thereafter, genotype effects on MRI-derived functional brain activation rather than protein expression were studied, with a focus on working memory-dependent brain activation [6]. A meta-analysis of effect sizes reflecting the association of genetic variance with brain versus behavioral data confirmed that the assessed genetic variants displayed stronger associations with brain function than with cognition or clinical symptoms [7, 8]. However, many early candidate gene study findings failed to replicate and meta-analyses showed that the observed associations between genotype and functional activation were smaller than originally assumed [9]. In fact, most early studies were not sufficiently powered to reliably produce large effect sizes. Moreover, a variety of disease-related as well as 
comorbid factors including smoking or stress hormone activation can interact with genotype effects on brain correlates $[10,11]$, requiring adequate sample sizes to address complex interactions.

To address the issue of statistical power and to confirm whether brain structures and functions are directly associated with genetic variance or are a secondary consequence of the disorder (e.g., due to pharmacological drug effects), prospective long-term studies are required, which assess young participants before the manifestation of symptoms or clinical disorders. For this purpose, the IMAGEN consortium was established in 2010. It includes 8 European centers; each of them recruited at least 250 healthy adolescents aged 14, who have been followed up at ages 16, 19, and 22 [12].

Another important benefit of the shift towards large multidisciplinary collaborations such as IMAGEN and $\mathrm{ABCD}[13]$ is that it allows for data driven discovery science and out-of-sample prediction for in vivo imaging genetics researchers. The initial IMAGEN sample size (>2000) was large enough to assess the effect of previously identified SNPs or polygenic risk scores on functional activation and their interaction with additional factors including environmental measures [14-16] and comorbid factors such as smoking or stress hormone activation $[10,11]$. Although not large enough for candidate gene or polygenic score construction [17], a phenotypically rich longitudinal dataset like IMAGEN is uniquely placed to identify how genes and behavior relate via psychological or neurobiological intermediate phenotypes.

Since its inception, the IMAGEN consortium has published a number of significant papers investigating how genetic and imaging findings contribute to specific traits, behaviors, symptoms, and disorders, for example with respect to impulsive decision making and drug consumption $[18,19]$. Despite the $100+$ IMAGEN publications in the last decade, no systematic review of IMAGEN findings has been published to date. Here we present all original IMAGEN imaging genetics papers, i.e., papers assessing effects of genetic variation on brain structure or functional brain activation during either reward anticipation, behavioral inhibition or processing of affective faces, and discuss their respective behavioral correlates with a focus on drugs of abuse including alcohol, tobacco, and cannabis.

\section{Methods}

\section{Data sources}

A systematic search for all IMAGEN publications was carried out by LMM and AR between October 1st, 2016, and December 31st, 2018. Relevant studies were identified using the list of published papers provided online by the IMAGEN consortium (https://imagen-europe.com/publica tions/) and by systematically searching the PUBMED database using the search terms "IMAGEN" and "consortium." Study references of identified articles were additionally reviewed and taken into account. Altogether, we identified a total number of 110 papers from the IMAGEN consortium including manuscripts with IMAGEN as a contributor. Among these, 62 publications report interactions between genotype and functional or structural brain data.

\section{Study selection}

To provide a systematic account of all papers published by the IMAGEN consortium, we reviewed all identified papers. Abstracts were screened for relevance, and all identified articles were discussed by LMM, HW, AR, and AH. We excluded studies that were systematic literature reviews and animal studies that were not using the IMAGEN sample of participants (Fig. 1).

We categorized papers from the IMAGEN consortium with respect to whether genetic variations were associated with (1) structural brain measures or (2) with one of the three tasks applied for functional imaging, i.e., the stop signal task (SST), the monetary incentive delay task (MID) and the Emotional faces (EF), or (3) intake of drugs of abuse. The variety of genetic variants addressed in IMAGEN studies was classified into four categories with respect to the main function of putatively associated genes: (1) neurodevelopment, (2) apoptosis and cell cycle, (3) neurotransmission, and (4) metabolic or endocrine function $[20,21]$.

To facilitate further use of the papers by the scientific community, we created three tables with key findings of all imaging genetics papers published by the IMAGEN consortium. The tables provide a brief overview of every paper, listing the title of the paper, authors, journal, year, the single

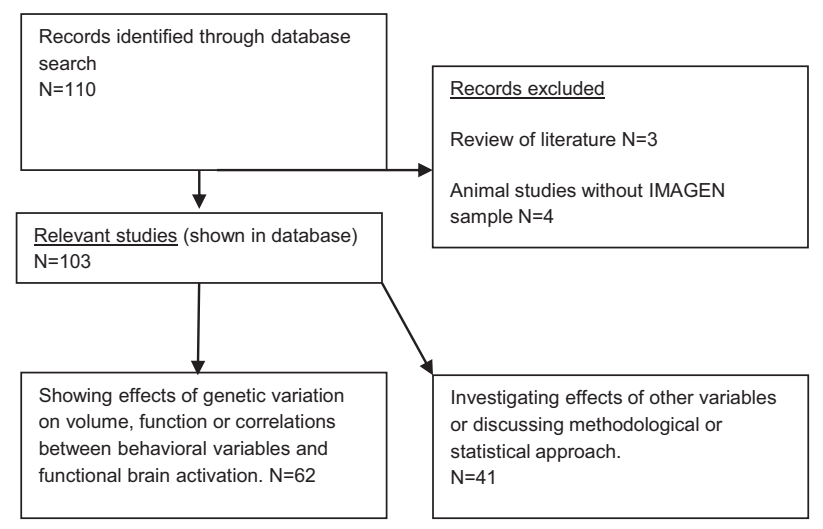

Fig. 1 Selection process. Flow-chart of selection process of identified publications. 
nucleotide polymorphisms (SNPs) investigated and the key imaging variable (brain volume, structure, or functional task) addressed by the study. Genotype effects are discussed with respect to findings of other papers by the IMAGEN consortium and by independent groups.

From the 110 papers, 7 were reviews that did not contain original data or focused exclusively on animal data; these 7 papers are not further discussed in this review. The remaining 103 studies reviewed here include 41 papers that focused on methodological issues or behavioral features, while 62 manuscripts reported genotype associations with brain structure or function or correlations between behavioral variables and functional brain activation.

\section{Results}

\section{Description of identified studies}

We identified 103 relevant original papers including published abstracts. Among these papers, 12 manuscripts reported associations between genetic variations and brain volume $[4,14,19,22-30]$ (Table 1). Furthermore, 16 manuscripts reported associations of genetic variation on functional brain activation elicited by the MID task [15, 31-45]; 6 papers described functional brain activation elicited by the SST [16, 18, 46-49], and 4 papers showed functional brain activation elicited by the EF [50-53] (Table 2). We identified 24 papers that did not address imaging genetics but reported correlations between behavioral variables and functional brain activation elicited by (1) the MID task $(n=13)$ [54-66], (2) the SST $(n=3)$ [67-69], and (3) the FRT $(n=8)$ [70-77] (Table 3).

Another 41 papers investigated methodological or statistical approaches or the associations of some other variables not listed above (e.g., maternal smoking and video gaming) on brain imaging parameters and behavioral variables and therefore were not included in the supplementary tables [12, 78-117].

From the multitude of findings, we here focus on brain regions relevant for drug use, including the hippocampus, striatum and frontal cortex. Drug use frequently starts during adolescence and has been a focus of IMAGEN research [55-59]. Figure 2 illustrates the potential of a simultaneous assessment of the effect of genetic variations on brain structure, function and behavior, using as an example the effects of genetic variation on (1) the volume of frontal, hippocampal, amygdala and striatal brain areas, (2) functional activation during reward anticipation and feedback, behavioral inhibition, and (3) alcohol, tobacco, and cannabis consumption. We also indicate whether structure or function of the respective brain regions were themselves directly associated with drug consumption.

\section{Genotype effects on brain structure relevant for drug use}

With respect to brain structure, frontocortical, hippocampal, and striatal (especially putamen) volumes were associated with variation in genes that contribute to metabolic and endocrine function, cell cycle and apoptosis, neurodevelopment and neurotransmission (Table 1). Notably, only variation in the HRK ("Between Harakiri, BCL2 Interacting Protein") gene, which has been associated with cell cycle and apoptosis [20], contributed to both hippocampus and putamen volume [4, 25] (Fig. 2), indicating that the genetic contribution to brain volumes in adolescence may be rather site-specific. The other polymorphisms associated with brain volume at age 14 contribute to metabolic and endocrine function (APOE), cell cycle and apoptosis (BABAM1, FBXW8, HMGA2, DDR2, HRK, BCL2L1, HMGA2, and Efhd2), neurodevelopment (NR2F6, USHBP1, DCC, and FAT3), and neurotransmission (DLG2, CHR1, CNR1, and NPTN). The longitudinal design of the IMAGEN study will help to assess whether the effects of these genetic variations on brain volume are also age dependent [4, 14, 19, 22-28].

\section{Genotype effects on functional brain activation relevant for drug use}

With respect to reward anticipation and feedback (Table 2 and Fig. 2), functional activation elicited by the MID task was associated with polymorphisms in genes influencing neurodevelopment (TNM4 and BDNF) [15, 39] and neurotransmission (DRD2/ANKK1 and MAOA) [36, 38]. Further, lower striatal activation during reward anticipation was associated with a high risk-taking bias (i.e., a strong tendency to engage in risky behavior) [59], while no significant difference was observed between adolescents with and without family history of alcohol use disorder [56].

With respect to the SST, distinct brain networks were associated with drug use versus attention deficithyperactivity symptoms; this study also reported that genetic variation in the norepinephrine transporter gene SLC6A2 was associated with the use of illegal substances but not functional activation elicited by behavioral inhibition [18]. The Arf6 activator Efa6/PSD3 was associated with ethanol-induced sedation and reduced tolerance development in drosophila and with altered prefrontal cortex activation during behavioral inhibition in the IMAGEN sample [46]. Moreover, epigenetic variation in the PPM1G gene locus was associated with increased functional activation of the right subthalamic nucleus during behavioral inhibition [16], and epigenetic modification of the OPRL1 gene mediated the effect of psychosocial stress and neutral striatal activation in the MID task on binge drinking in adolescence [31]. 


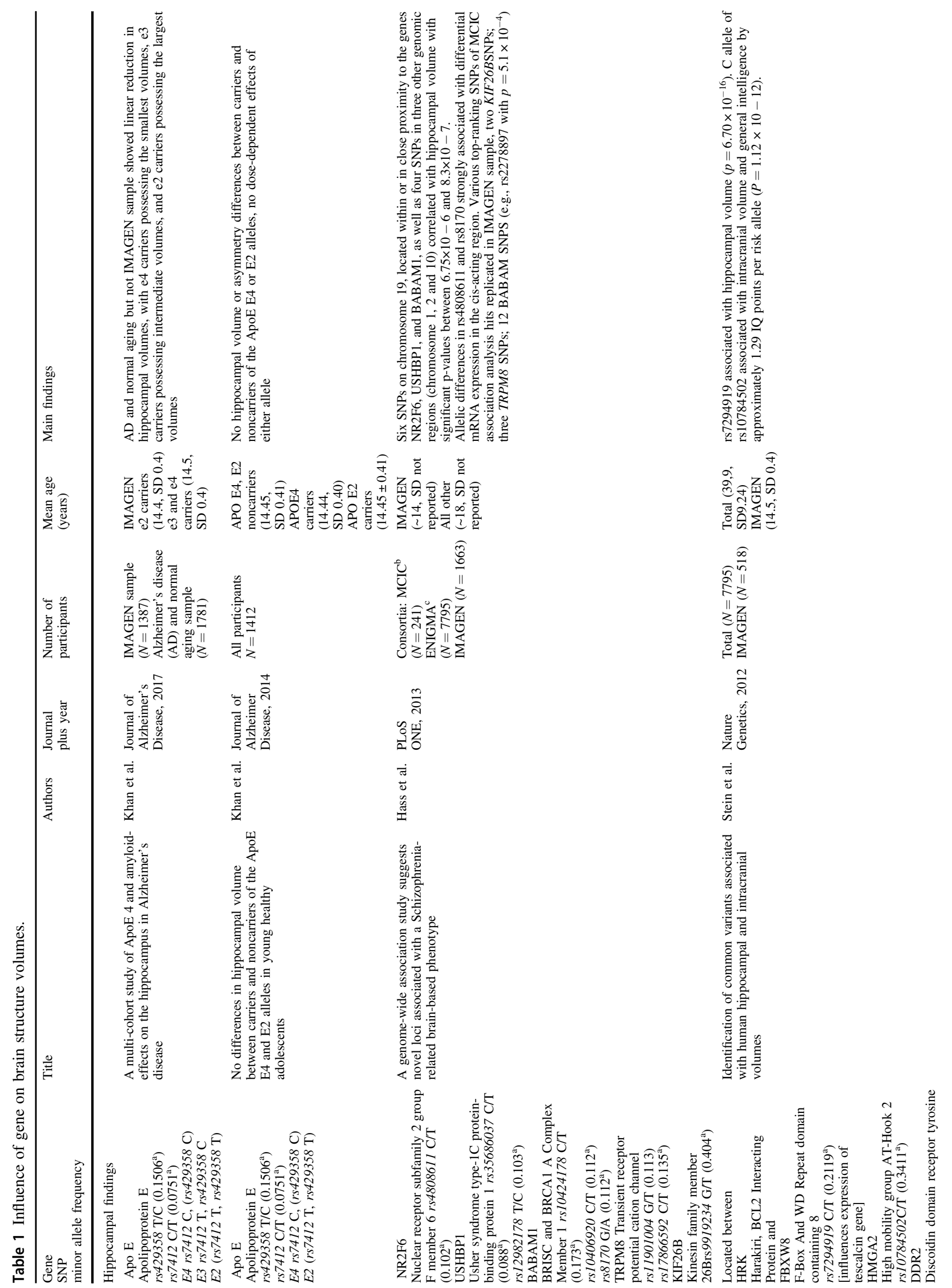




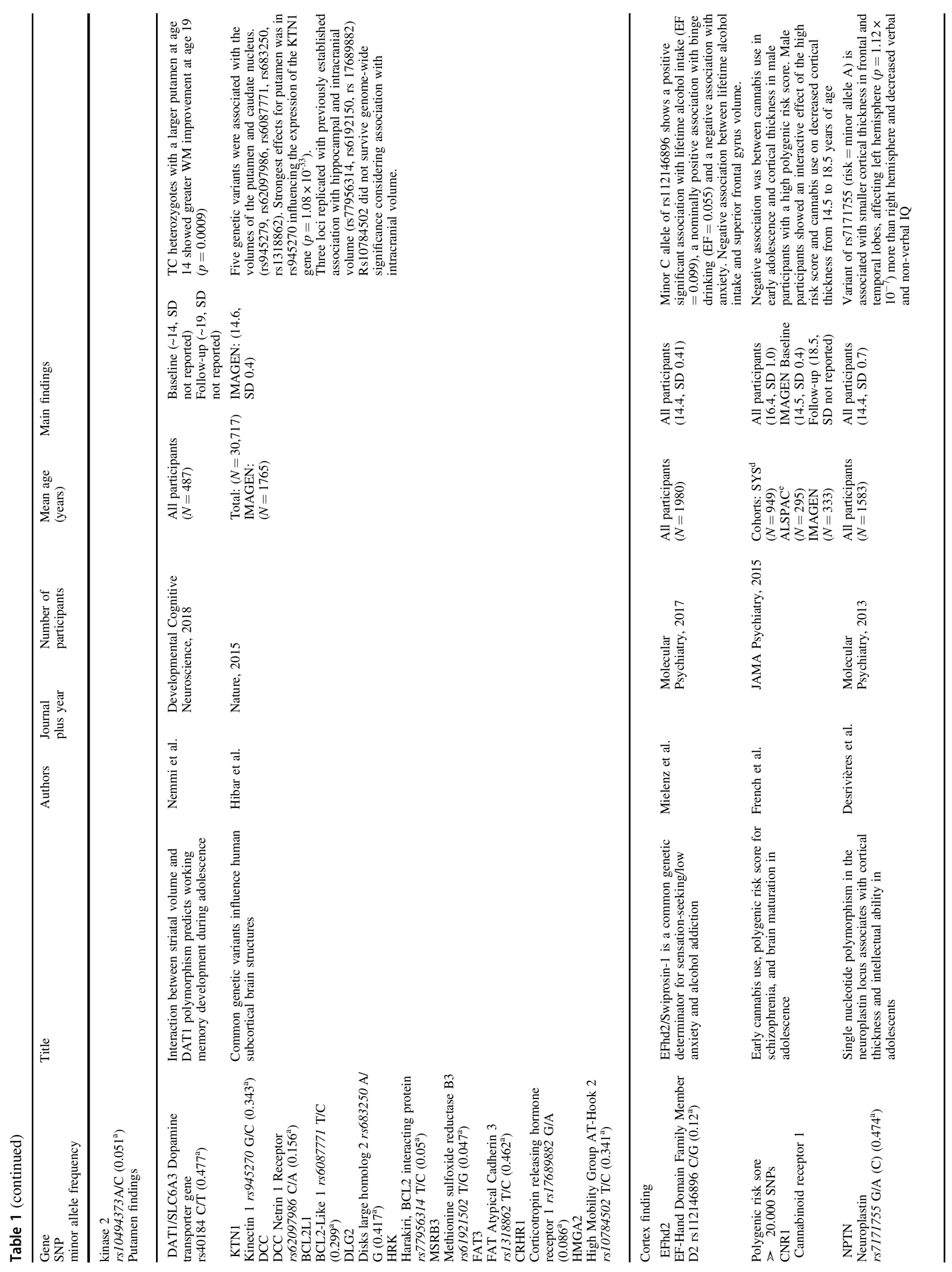




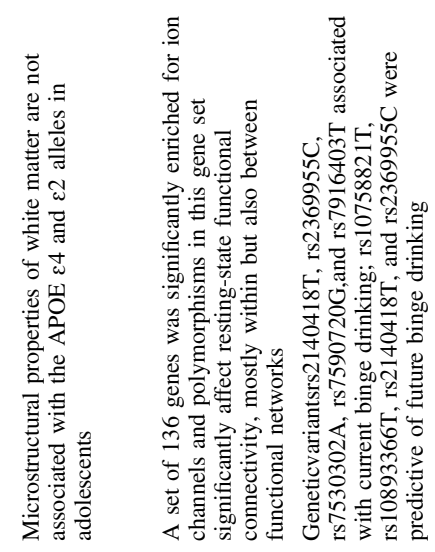

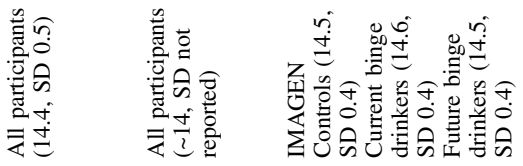

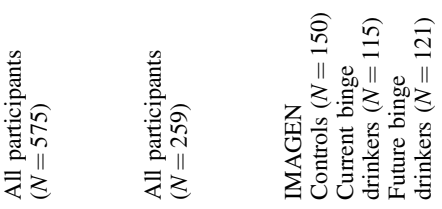

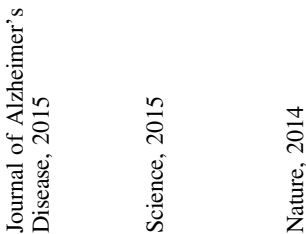

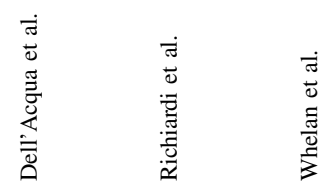

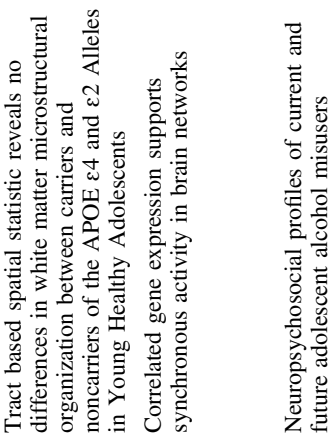
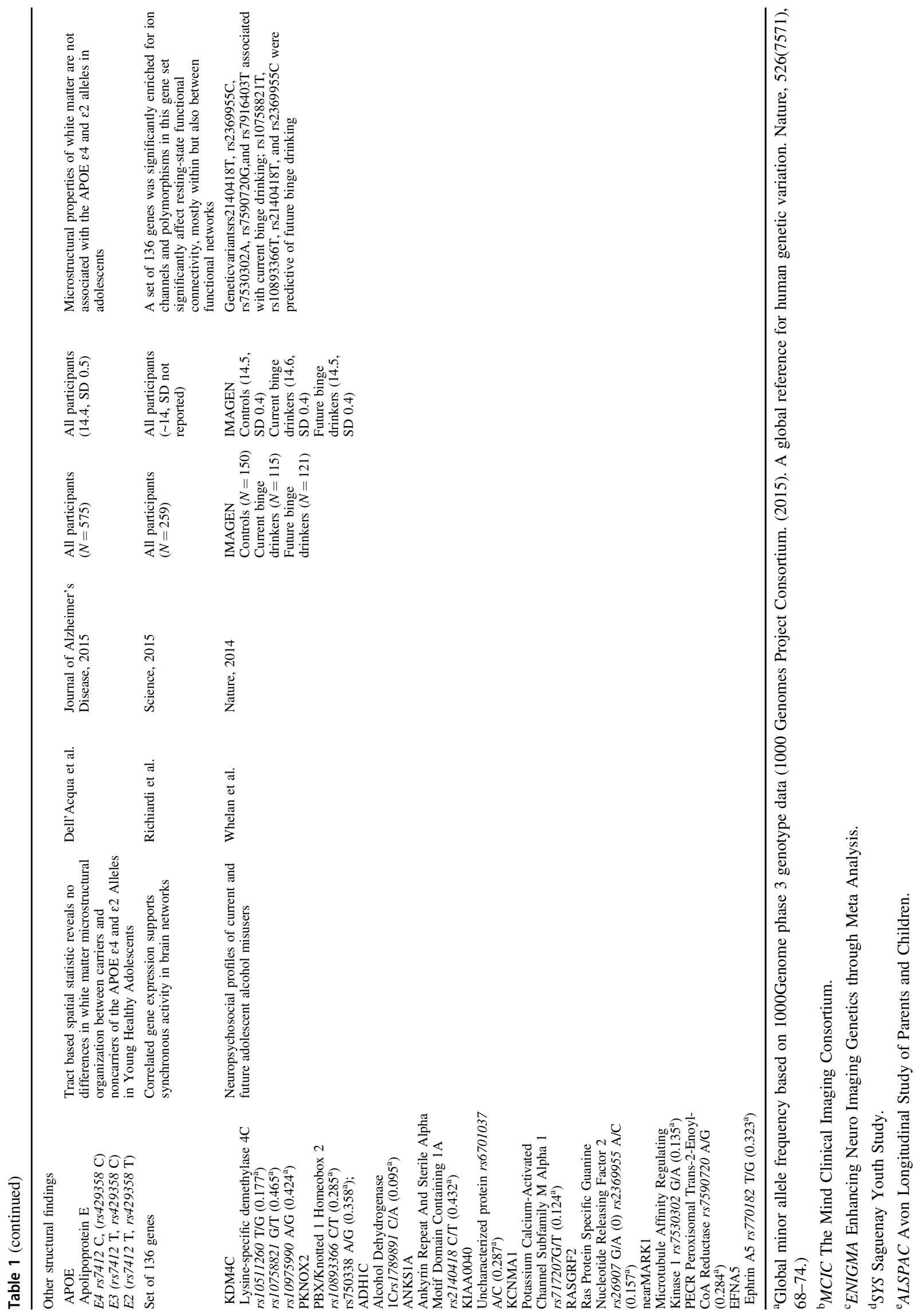


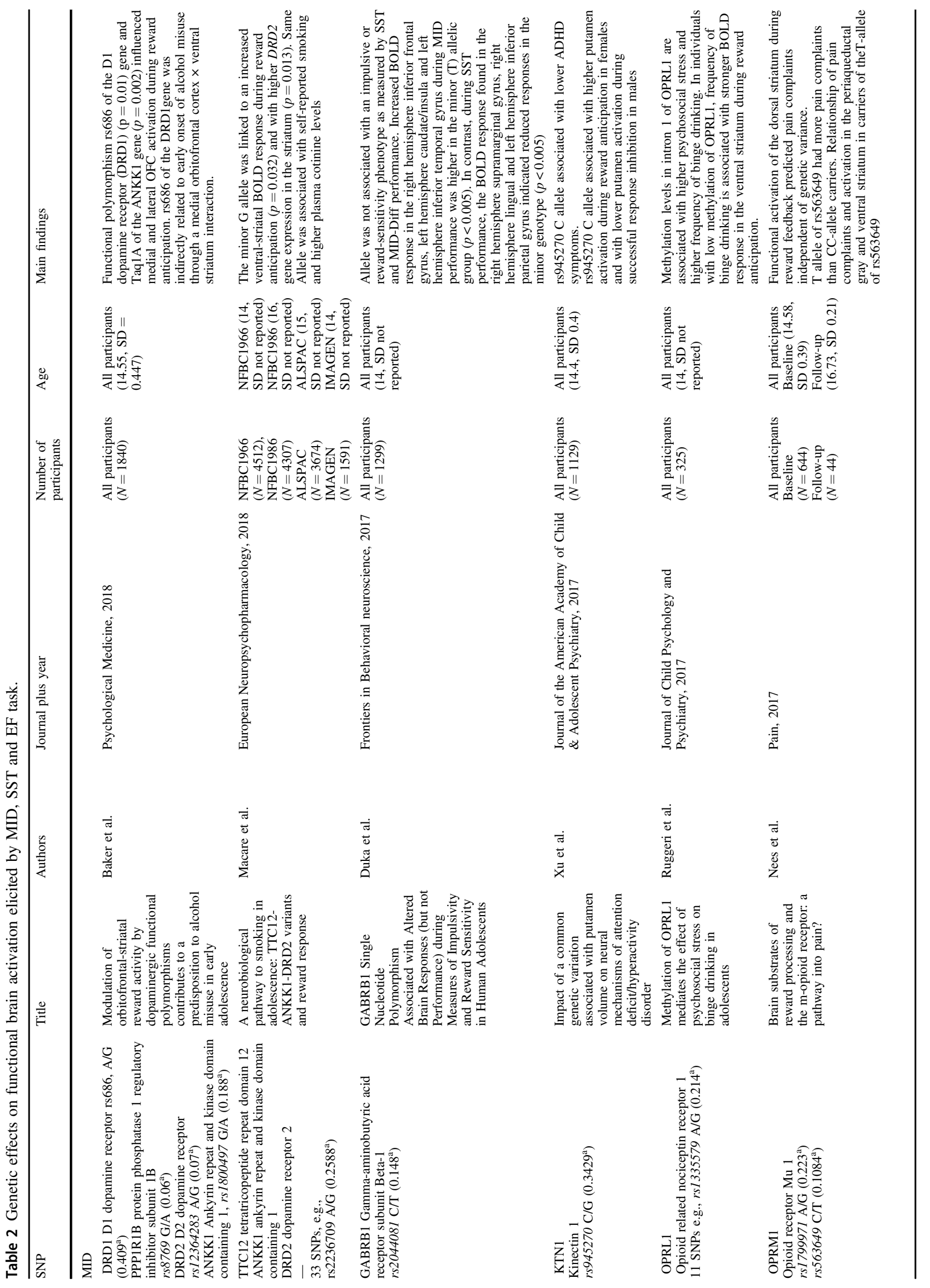




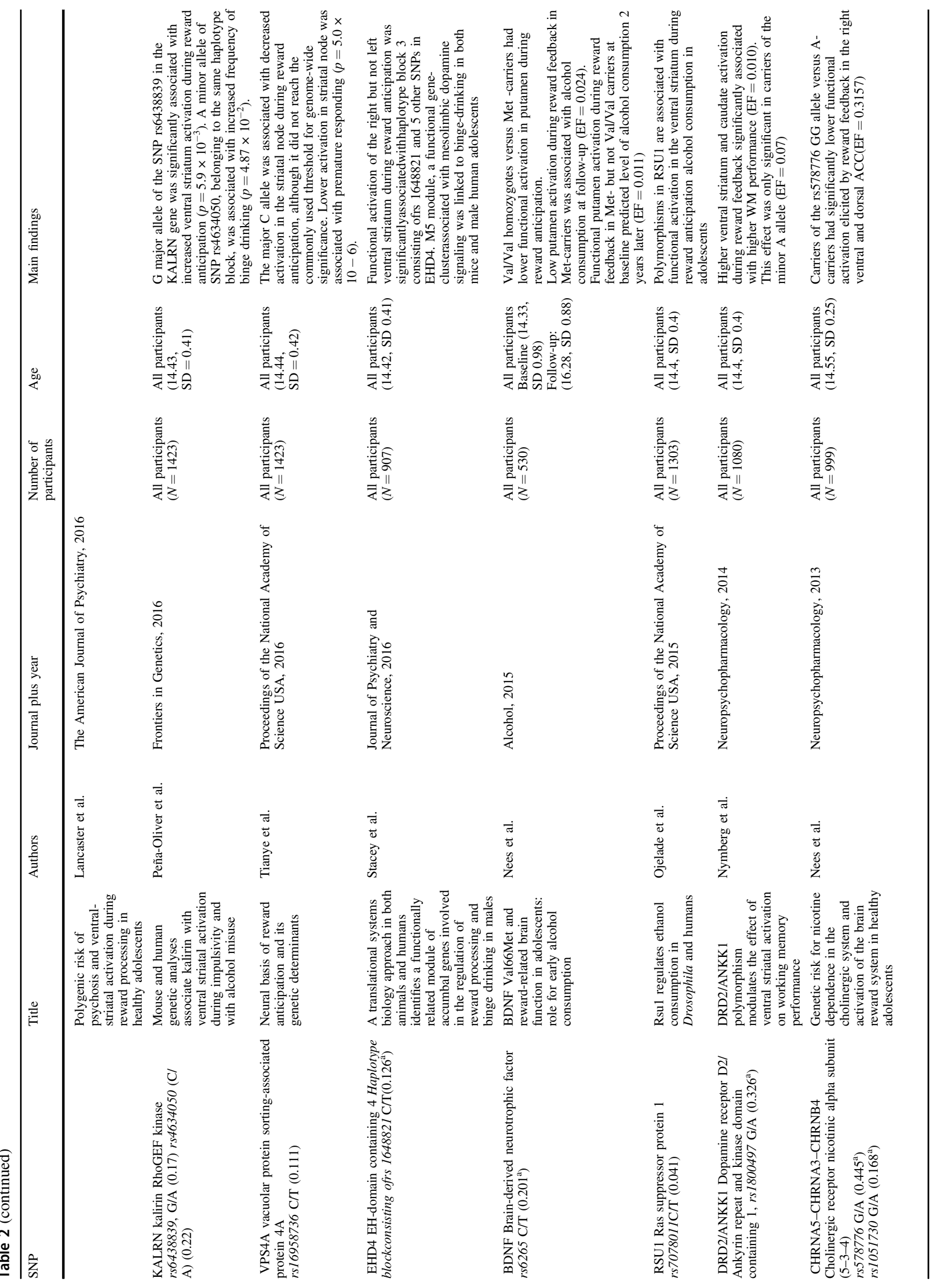




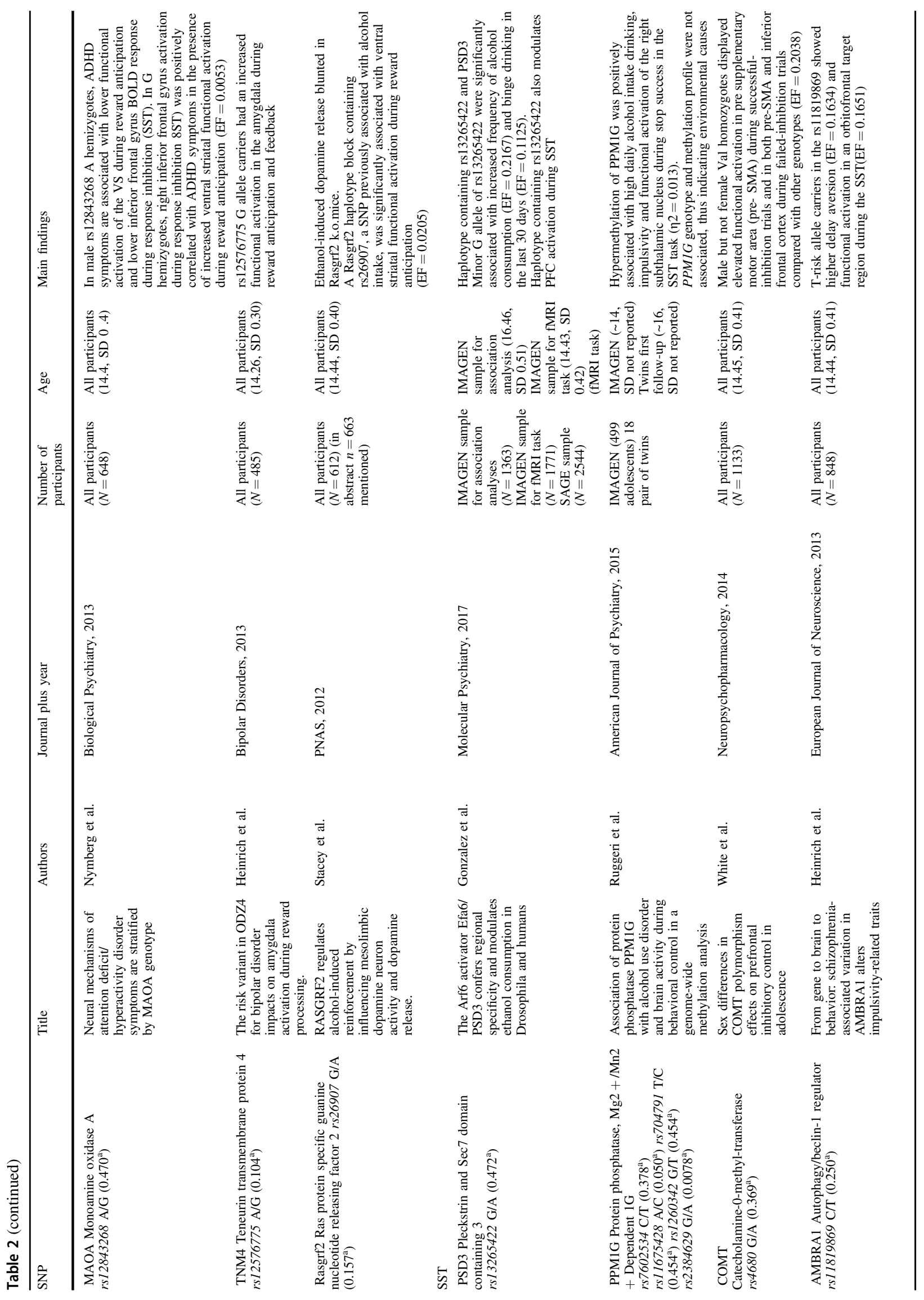




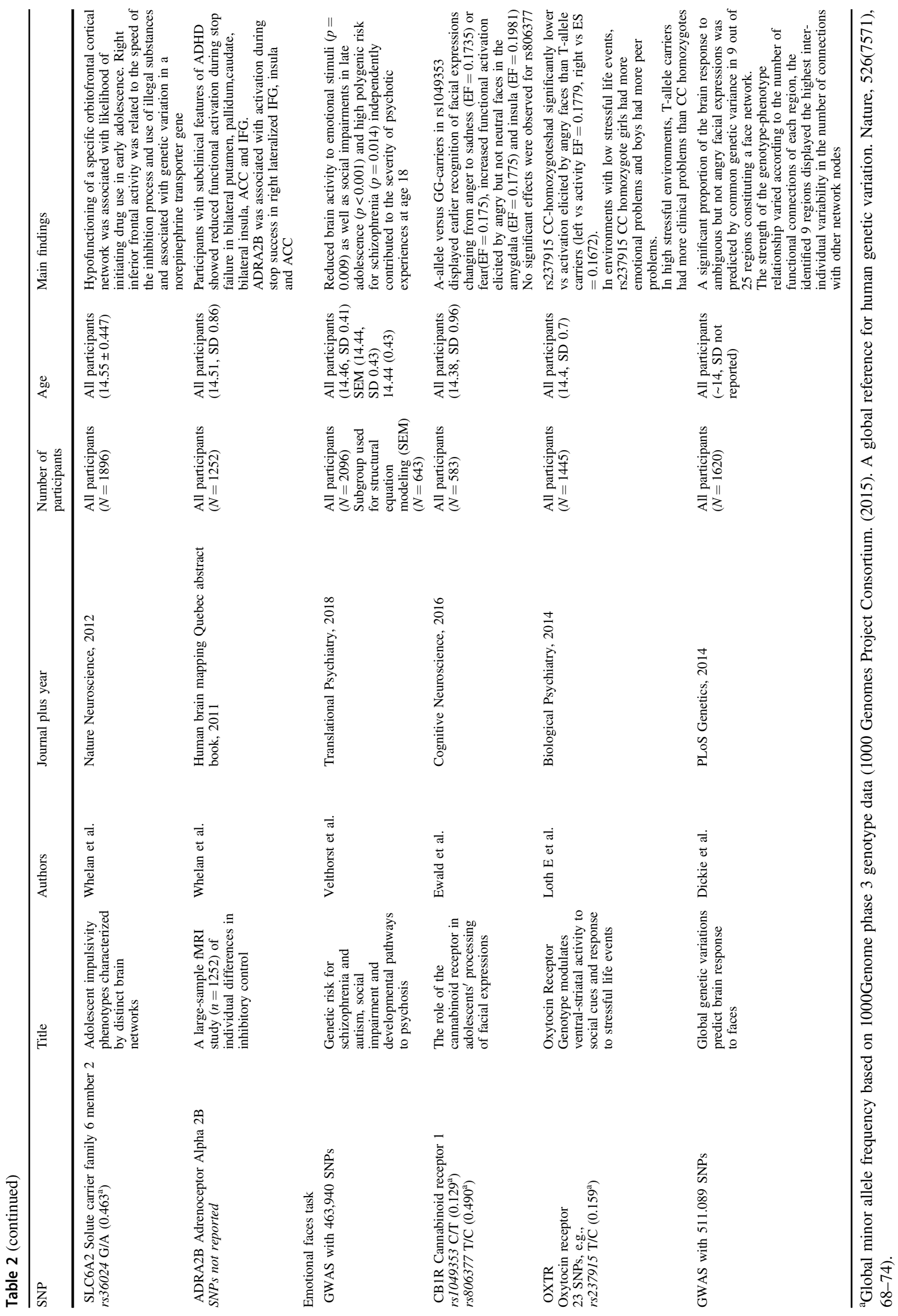


Regarding the EF paradigm, genetic variation in CB1R was associated with activation of the bilateral amygdala to angry faces, which in turn was correlated with higher drug intake [18].

\section{Genotype and other associations with drug use}

With respect to alcohol consumption, Fig. 2 shows genes associated with alcohol intake in the 30 days before study inclusion. The EHD4 gene, which has been associated with the cell cycle and apoptosis [21], showed a statistically significant association with alcohol consumption at age 14 [34]. Neuroimaging data additionally showed that low functional activation of the ventral striatum and of the putamen during reward anticipation at age 14 predicted high alcohol intake at age 16, with the association between functional putamen activation and alcohol intake being mediated by the BDNF Val66Met polymorphism [19]. The above mentioned epigenetic variation in the PPM1G gene was associated with high impulsiveness and early escalation of alcohol use [16]. Also, the human ortholog sof the Arf6 and Erf6 genes were associated with increased frequency of drinking and binge drinking episodes [46].

With respect to cannabis and other illegal drugs consumption, genetic variation in the norepinephrine transporter gene was associated with hypoactivation of the right inferior orbitofrontal network and speed of motor inhibition during SST, which was correlated with higher drug intake [18].

With respect to nicotine consumption, lower striatal activation during reward anticipation correlated with prenatal exposure to maternal smoking [57]. Risk variant rs578776, a variant in the CHRNA5-CHRNA3-CHRNB4 gene cluster, influences susceptibility to nicotine dependence by dampening the response of the anterior cingulate cortex to reward feedback, without recruiting the striatum or orbitofrontal cortex during feedback or anticipation [37].

\section{Discussion}

The IMAGEN study has identified several genetic polymorphisms that interact with adolescent brain function and behavior, thus helping to disentangle their general functional roles [16, 46, 50]. With 2000 adolescents aged 14 when included in the study, the IMAGEN cohort was the largest sample available to date for imaging genetics analyses, thus improving power compared with previous studies with smaller sample sizes [118]. Due to its longitudinal design, the IMAGEN study can help to reveal geneenvironment interactions in the manifestation of mental disorders from adolescence to and young adulthood.
From the large body of IMAGEN publications, we focused on findings of genes interacting with (1) brain volume, (2) functional activation, and (3) drug intake, which tends to start during adolescence and has repeatedly been attributed to gene-environment interactions $[18,55]$

To explore psychopathology-relevant brain functions, we selected tasks that probe key aspects of reinforcementrelated behaviors and emotional processing implicated in frequent neuropsychiatric disorders: response inhibition, emotional reactivity, and reward sensitivity. The neuroimaging tasks were chosen because they reliably elicit strong activation in functional networks underlying inhibitory control (SST) [119], emotional reactivity to social stimuli (EF) [120] and reward anticipation/outcome (MID) [121]. Some limitations of using these three tasks include incomplete assessment of different aspects of behavioral constructs, e.g., SST measuring motor impulsivity but not delay discounting, which was assesed behaviorally; passive reception of socially salient stimuli (faces) outside of social context; lack of possibilities for computational modeling of reward-related decisions in the MID task.

The IMAGEN study has assessed a wide range of environmental factors including childhood trauma, bullying, stressful life events, family mental health, pre- and perinatal events, and family conflict. For example, peer victimization was indirectly associated with increased anxiety via decrease in left putamen and caudate volume [114]. Moreover, stressful life events were associated with the interaction between functional amygdala activation elicited by the EF task in adolescents with conduct and hyperactivity symptoms [71]. We here describe genetic and environmental effects on brain structure, function, and behavior assessed in the IMAGEN study.

Regarding reward anticipation and feedback, the IMAGEN consortium focused on polymorphisms implicated in both impulsive and addictive behavior. Reduced ventral striatal activation during reward anticipation has repeatedly been observed in alcohol-dependent patients and may be attributed to dopamine dysfunction following detoxification $[2,122]$. However, it was unclear whether reduced activation during reward anticipation is present prior to the development of alcohol use or alcohol use disorder. Here, Büchel et al. [55] observed that reduced functional activation of the ventral striatum, midbrain, and prefrontal cortex at age 14 predicts drug use at age 16. Environmental factors that may contribute to such a blunted ventral striatal activation include maternal smoking during pregnancy [57]. Blunted ventral striatal activation in adolescents has been associated with increased impulsivity [60], a finding that replicates a similar observation in adult alcohol-dependent patients and controls [123]. Moreover, impulsivity has been associated with early life stress, [2] and methylation of the OPRL1 gene was shown to mediate the effect of 


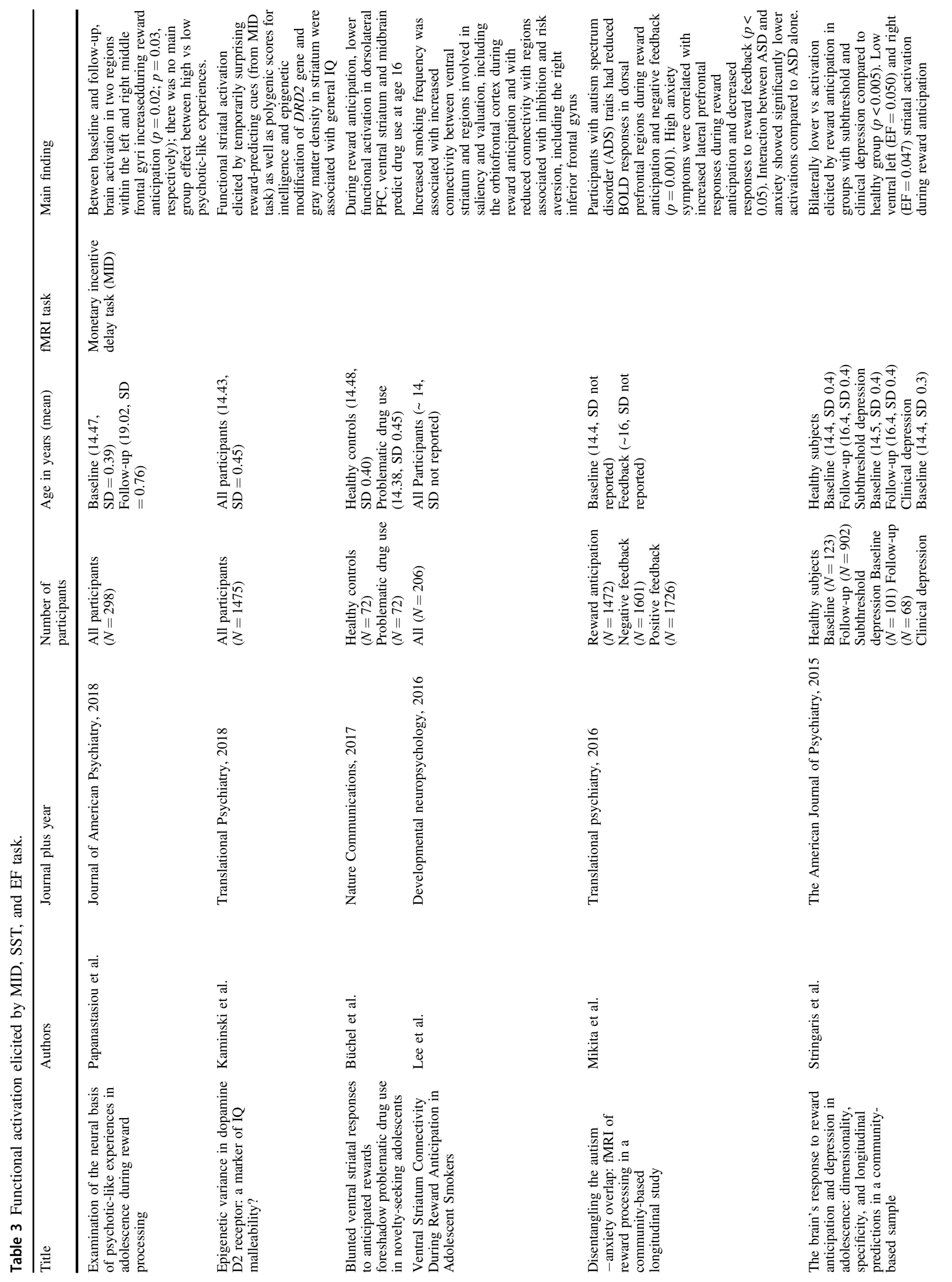




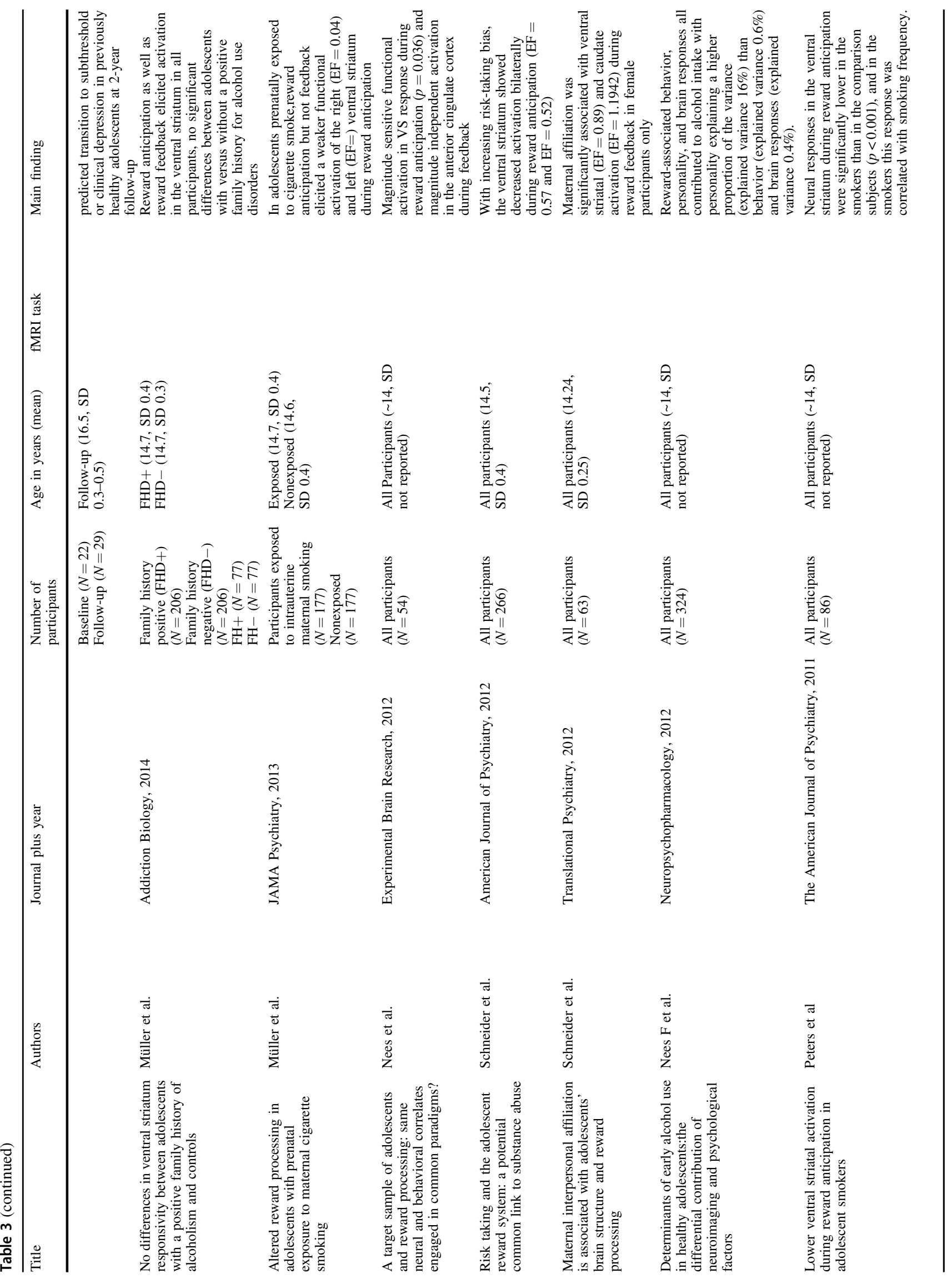




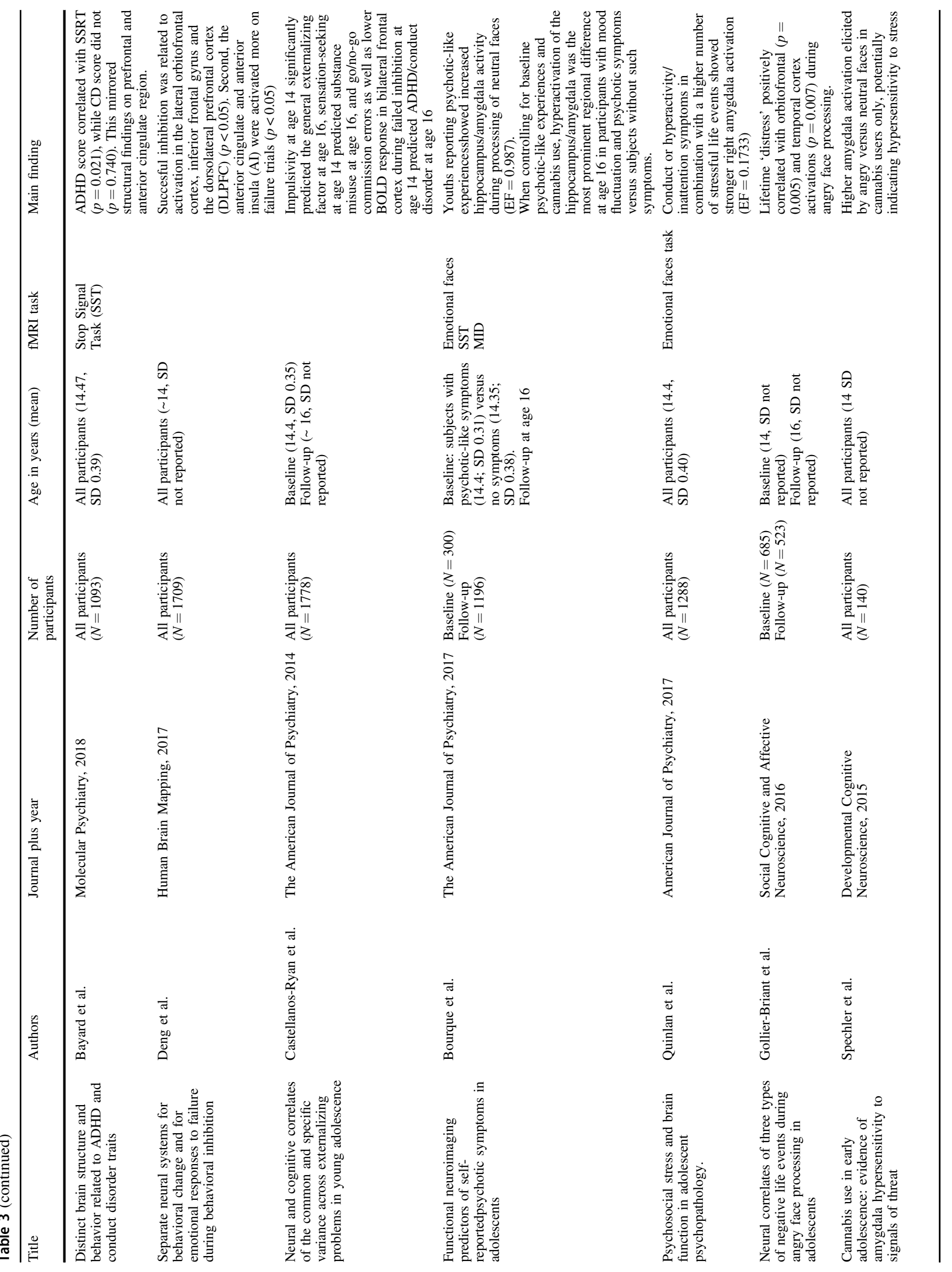




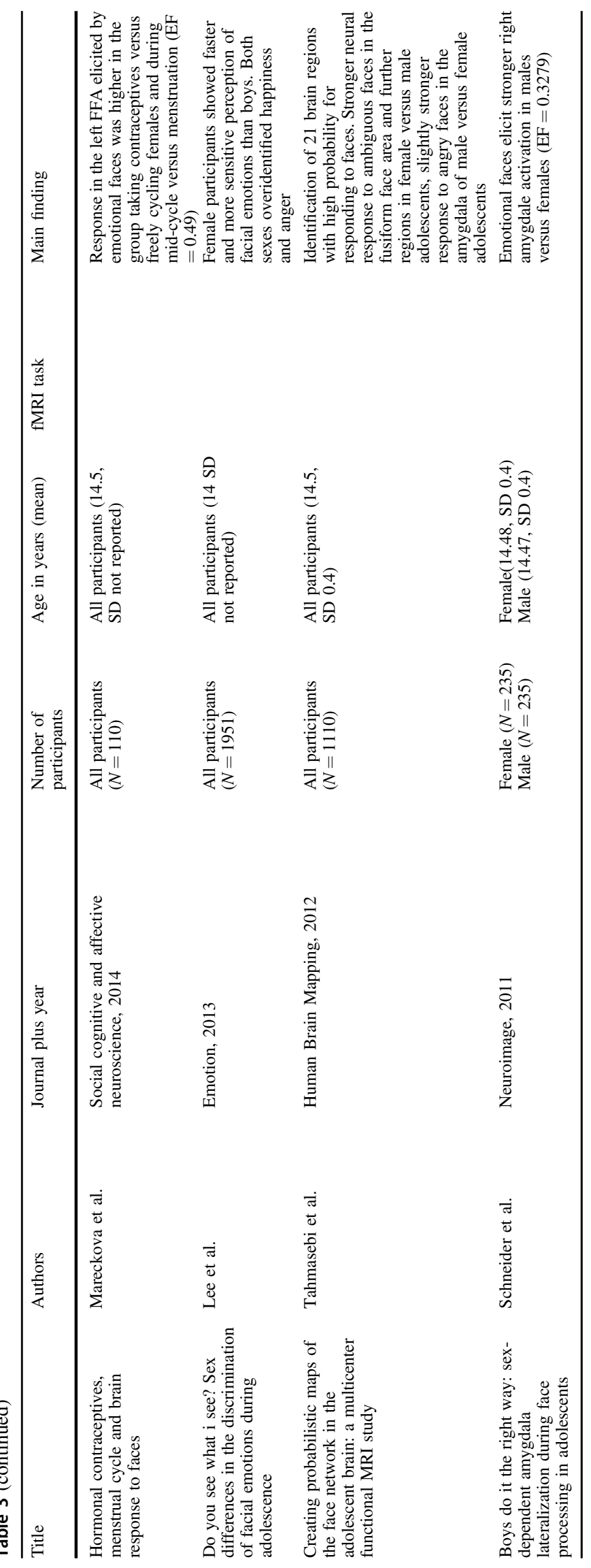




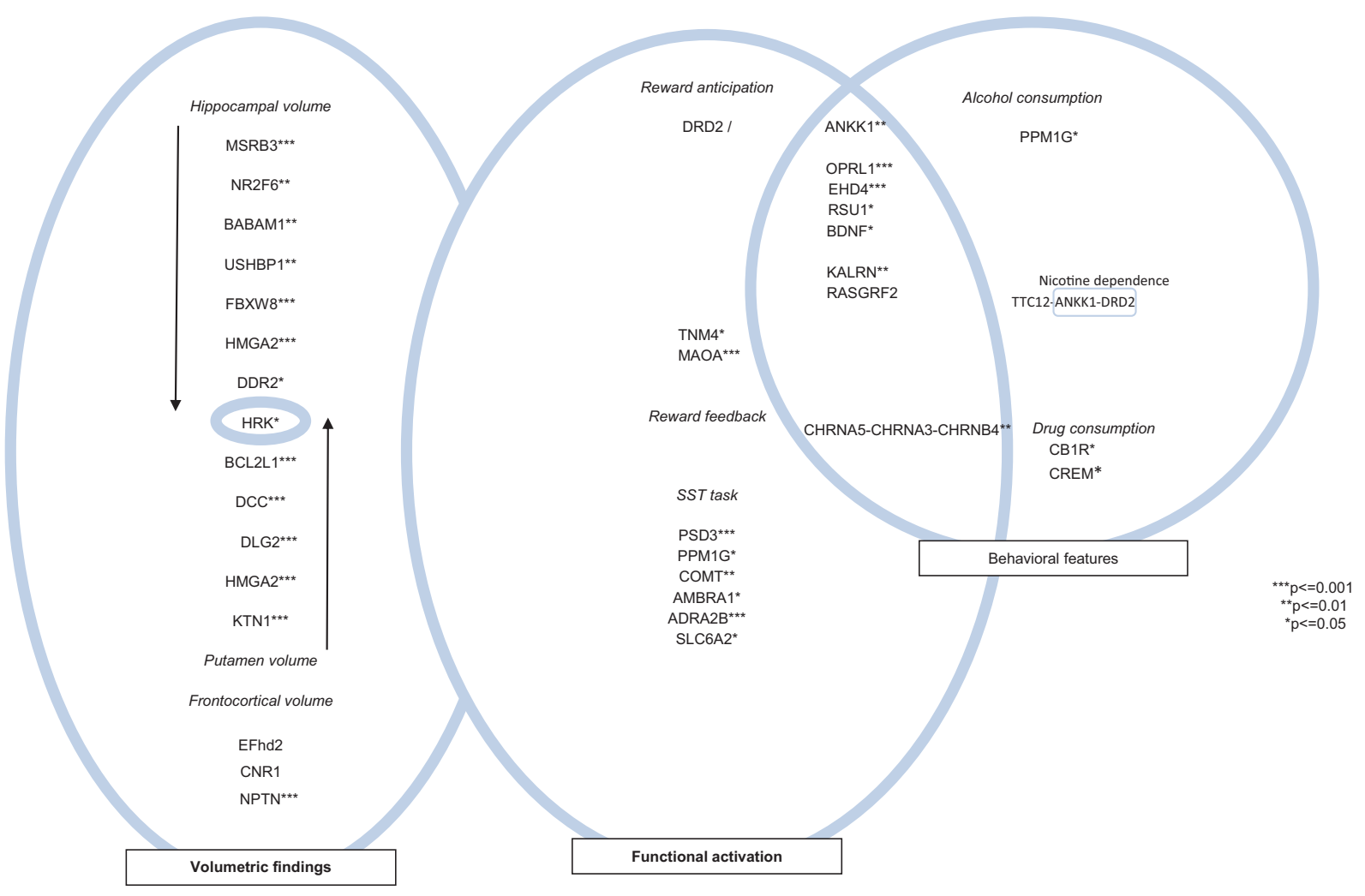

Fig. 2 Effect of genetic variations on brain structure, function and behavior. Genes and epigenetic modifications associated with brain structure (hippocampus and putamen volume), functional activation (reward anticipation and feedback as elicited by the MID task; SST task) and behavior (alcohol consumption, nicotine and cannabis consumption).

psychosocial stress on impulsive alcohol intake (binging) and the associated ventrostriatal activation in adolescence [31]. The OPRL1 genotype has repeatedly been replicated on alcohol use disorders [124, 125].

Beyond environmental factors, genetic variance contributes to reduced ventral striatal activation during reward anticipation elicited by cues that predict reward. In humans, Stacey et al. [40] observed an association between reduced functional activation of the ventral striatum and a haplotype block containing the Rasgrf2 polymorphism rs 26907 , which was associated with alcohol intake in a previous metaanalysis [126]. In animal experiments, Stacey et al. [40] observed that Rasgrf2 knockout mice displayed a significant reduction in ethanol intake relative to wild type controls, lower intake at the highest ethanol concentrations, and blunted diurnal drinking. Rasgrf2 knockout mice also showed a significant reduction in ethanol preference, which was measured by the percentage of ethanol relative to water intake [40]. In addition, Rasgrf knockout mice showed a diminished noradrenergic and serotonergic response in the ventral striatum/nucleus accumbens and a decrease in $\beta 1$ adrenoreceptor gene expression [127]. Easton and colleagues have shown that Rasgrf 2 mediates the presence of noradrenaline (NA) and serotonin (5-HT) in the synaptic cleft at both basal level and after acute alcohol exposure.
After subchronic alcohol exposure, the NA system is modified, and Rasgrf2 regulates alterations in expression levels of adrenoceptor mRNA. Rasgrf2 may be a mechanism by which the NA system is prevented from adapting to subchronic alcohol intake, which could in turn influence vulnerability to the effects of repeated alcohol exposure [128]. Moreover, it was shown that Rasgrf2 controls dopaminergic signaling and adaptations to alcohol also in other brain regions, beyond the nucleus accumbens [127]. Another Rasgrf2 polymorphism (rs2369955) was associated with current and future binge drinking in the IMAGEN cohort [19]. Therefore, the IMAGEN findings regarding Rasgrf2 are neurobiologically plausible, however, replication in an independent imaging sample has yet to be done.

These IMAGEN findings can be explained by the fact that Rasgrf2 interacts with activation of the MAPK/ERK pathway, which is involved in neurotransmission through dopamine receptors and transporters and thus potentially associated with dopamine-dependent reward mechanisms in alcoholism [129, 130]. In mouse models, ethanol administration increased ERK activity in the nucleus accumbens, and inhibition of ERK activity influenced ethanol selfadministration [19].

Further genetic variance impacting on ventral striatal activation was discovered by Nees et al. [15], who showed 
that BDNF Val homozygotes compared with Met carriers had lower putamen reactivity during reward anticipation. This is in partial accordance with results from Pecina et al., who also observed effects of BDNF ValMet genotype on functional activation during the anticipations of rewards and losses, albeit only significant during loss anticipation [131]. Lower striatal activation during reward anticipation may impact on personality traits reflecting the orientation towards positive reinforcers. Benzerouk et al. [132] indeed observed that BDNF Val carriers with a positive family history for alcohol use disorders displayed lower levels of reward dependence compared to probands without such a family history. ValMet genotype was also associated with risk of relapse in alcohol dependence, however, no functional brain imaging was performed in the study [133]. Furthermore, the BDNF Val68Met polymorphism regulates $\mathrm{BDNF}$ expression and was also implicated in rodent models of uncontrolled and excessive alcohol intake [134]. BDNF expression was lower in the nucleus accumbens [135] and in the central and medial nucleus of the amygdala of alcohol preferring versus non-preferring rats [136], and short versus long-term alcohol intake differentially regulate BDNF mRNA levels in the nucleus accumbens in rats actively versus passively consuming alcohol [137].

With respect to a dimensional approach towards mental disorders [138], the IMAGEN consortium also assessed whether blunted ventral striatal activation elicited by reward indicating cues is associated with psychotic or affective symptoms and disorders. Previous studies showed that low functional activation of the ventral striatum during reward anticipation in patients with depression and schizophrenia was related to the severity of negative mood states including depression and anhedonia [139, 140]. In the IMAGEN adolescents, Stringaris et al. [54] observed that low ventral striatum activation during reward anticipation at age 14 predicted transition to subthreshold or clinical depression in previously healthy adolescents at age 16. Vulser et al. [89] observed that adolescents with subthreshold depression also had smaller gray matter volumes in the ventromedial prefrontal and rostral anterior cingulate cortex as well as in the putamen [25]. In 2018, Vulser et al. showed that early fractional anisotropy variations in tracts projecting from the corpus callosum to the anterior cingulate cortex may denote a higher risk of transition to depression in adolescents [112]. Findings regarding the cingulate cortex volume are interesting in light of their association with major depression [141] and the role of this brain area in error detection and behavioral control [142], which may also play a role in recovery from affective disorders. Indeed, patients with sustained activation elicited by reward feedback across task runs in the anterior cingulate cortex were more responsive to behavioral activation therapy [143].
With respect to higher cognitive functions, Nymberg et al. [36] showed that higher ventral striatal and caudate activation during reward feedback was associated with higher working memory performance and that this interaction was limited to A allele carriers of the DRD2/ANKK1 polymorphism. Also Taq1A of the ANKK1 gene interacted with a lateral orbitofrontal activation during reward anticipation [45] and predicted alcohol drinking 2 years later [105]. These findings provide evidence for an interaction between reward processing and complex cognitive capacities [144, 145]. Differences in striatal dopaminergic neurotransmission have also been associated with differences in working memory performance [146, 147], in line with findings concerning dopaminergic markers and cognitive capacity [65].

Beyond reward anticipation and feedback, impulsivity as operationalized by behavioral inhibition has been implicated in the development and maintenance of substance use disorders [148]. The subthalamic nucleus modifies information processing in fronto-striatal networks relevant for impulse control [148, 149]. Increased functional activation of the subthalamic nucleus was associated with hypermethylation in the PPM1G gene, which also correlated with increased impulsiveness and alcohol use in adolescence [16]. Further brain areas implicated in behavioral inhibition are the prefrontal cortex [18], whose activation was associated with the human ortholog of Arf6 and orthologs of Efa6 (PSD1-4) [46].

Regarding the processing of affective faces, the study of Spechler et al. shows that stronger amygdala activation to signals of threat was associated with high cannabis intake. This observation points to another neurobiological dimension contributing both to negative mood states and drug intake [72]. Indeed, increased amygdala activation towards aversive stimuli has been shown to contribute to anxiety, feelings of being threatened and aggression, which in return predict excessive alcohol use [148]. Stronger amygdala activation during emotional processing was also observed in adolescents who experienced both a high number of stressful life events and strong symptoms of conduct disorder and hyperactivity [71], highlighting how experience can modulate brain-behavior relationships.

Overall, the IMAGEN consortium was able to detect a number of genetic polymorphisms with specific effects on brain structure and function and their association with symptoms of mental disorders in adolescents. IMAGEN's study design has supported the elucidation of biological and environmental mechanisms of substance use-related behaviors, but we note limitations and ways to address them. The rather large-sample size overcomes some of the limitations of previous genetic imaging studies, however, independent replications are required. As studies like IMAGEN have their data repeatedly used by researchers, 
which-if systematic errors existed in the data would then be propagated into all research output, strict quality assurance and quality control measures are taken by the central database team that has overseen data management across all study time points. This allows for quick identification and resolution of errors that could occur before data are released for analyses (i.e., data entry and data upload/transfer).

The very nature of multivariate multimodal approaches bears a multiple comparison issue. Fortunately, clinical samples and other large phenotypically rich studies such as UK Biobank provide the opportunity to externally validate IMAGEN findings. Resampling methods such as bootstrapping and cross-validation (e.g., leave-one-out and splithalf) are techniques we have used to internally validate model fit and estimate a model's generalizability [41]. Moreover, the IMAGEN consortium asks for research proposals before data access is granted, and thus prevents unethical data dredging. Nonetheless, exploratory data analysis can be performed and has to be clearly described as such. Replication of such a cohort might be very costly, that is why rigorous statistics including the above mentioned internal cross-validation for estimation of predictive power and the reporting of confidence intervals in order to describe a range of plausible estimates should be promoted. With respect to intraindividual variance, reliability measures as well as developmental changes replications can be carried out within the IMAGEN sample, e.g., by assessing whether the same polymorphisms impact on subcortical brain volumes at age 14 and 16 or in young adulthood. Given the multisite design, variance from different acquisition sites were considered based on a central protocol.

The issue of participant attrition over time may limit some longitudinal multimodal statistical modeling and internal validation methods (i.e., due to reduced power and incomplete data), but with more than 1300 participants assessed at age 22, there is still great opportunity to understand the influence of biology and the environment on developmental trajectories of substance use. Relevant to identifying gene-environment interactions on brain and behavior, the relatively homogeneous socioeconomic background of the Western European participating families meant IMAGEN was not well placed to investigate particular environmental influences such as nutrition or hazardous exposures. Furthermore, no resources were available to independently confirm the reliability of the self-reported environmental data.

For the purpose of genetic analyses, the IMAGEN participants are of European ancestry-as a result the generalizability of findings to other cultures and stress/ environmental exposures is unknown. Therefore, future replications should also be carried out outside of Europe, requiring careful harmonization of clinical tools and paradigms. As recently reported [150], the IMAGEN study has aligned itself with other global neuroimaging-genetics adolescent cohorts that will further enhance and clarify the work presented here.

Acknowlegements This work received support from the following sources: the European Union-funded FP6 Integrated Project IMAGEN (Reinforcement-related behavior in normal brain function and psychopathology) (LSHM-CT- 2007-037286), the Horizon 2020 funded ERC Advanced Grant 'STRATIFY' (Brain network based stratification of reinforcement-related disorders) (695313), ERANID (Understanding the Interplay between Cultural, Biological and Subjective Factors in Drug Use Pathways) (PR-ST-0416-10004), BRIDGET (JPND: BRain Imaging, cognition Dementia and next generation GEnomics) (MR/N027558/1), the FP7 projects IMAGEMEND (602450; IMAgingGEnetics for MENtal Disorders) and MATRICS (603016), the Innovative Medicine Initiative Project EU-AIMS (115300-2), the Medical Research Council Grant 'c-VEDA' (Consortium on Vulnerability to Externalizing Disorders and Addictions) (MR/N000390/1), the Swedish Research Council FORMAS, the Medical Research Council, the National Institute for Health Research (NIHR) Biomedical Research Centre at South London and Maudsley NHS Foundation Trust and King's College London, the BundesministeriumfürBildung und Forschung (BMBF grants 01GS08152; 01EV0711; eMED SysAlc01ZX1311A; Forschungsnetz AERIAL 01EE1406A, 01EE1406B), the Deutsche Forschungsgemeinschaft (DFG grants SM 80/7-2, SFB 940/2, TRR 265), the Medical Research Foundation and Medical research council (grant MR/R00465X/1). Further support was provided by grants from: ANR (project AF12NEUR0008-01-WM2NA, and ANR-12-SAMA-0004), the Fondation de France, the Fondation pour la RechercheMédicale, the Mission Interministérielle de Lutte-contre-les-Drogues-et-les-ConduitesAddictives (MILDECA), the Assistance-Publique-Hôpitaux-de-Paris and INSERM (interface grant), Paris Sud University IDEX 2012; the National Institutes of Health, Science Foundation Ireland (16/ERCD/ 3797), USA (Axon, Testosterone and Mental Health during Adolescence; RO1 MH085772-01A1), and by NIH Consortium grant U54 EB020403, supported by a cross-NIH alliance that funds Big Data to Knowledge Centres of Excellence. Open access funding provided by Projekt DEAL.

IMAGEN consortium Lisa Albrecht ${ }^{1}$, Chris Andrew $^{2}$, Mercedes Arroyo $^{19}$, Eric Artiges ${ }^{12}$, Semiha Aydin ${ }^{11}$, Christine Bach ${ }^{3}$, Tobias Banaschewski ${ }^{3}$, Alexis Barbot ${ }^{20}$, Gareth Barker ${ }^{2}$, Nathalie Boddaert ${ }^{12}$, Arun Bokde ${ }^{12}$, Zuleima Bricaud ${ }^{12}$, Uli Bromberg ${ }^{6}$, Ruediger Bruehl ${ }^{11}$, Christian Büchel ${ }^{6}$, Arnaud Cachia ${ }^{12}$, Anna Cattrell ${ }^{2}$, Patricia Conrod ${ }^{2}$, Patrick Constant ${ }^{21}$, Jeffrey Dalley ${ }^{19}$, Benjamin Decideur ${ }^{9}$, Sylvane Desrivieres $^{2}$, Tahmine Fadai ${ }^{6}$, Herta Flor ${ }^{3}$, Vincent Frouin ${ }^{9}$, Jürgen Gallinat $^{6}$, Hugh Garavan ${ }^{5}$, Fanny Gollier Briand ${ }^{12}$, Penny Gowland ${ }^{22}$, Bert Heinrichs $^{23}$, Andreas Heinz ${ }^{1}$, Nadja Heym ${ }^{22}$, Thomas Hübner ${ }^{16}$, James Ireland ${ }^{24}$, Bernd Ittermann ${ }^{11}$, Tianye $\mathrm{Jia}^{2}$, Mark Lathrop ${ }^{25}$, Dirk Lanzerath $^{23}$, Claire Lawrence ${ }^{22}$, Hervé Lemaitre ${ }^{12}$, Katharina Lüdemann $^{1}$, Christine Macare ${ }^{2}$, Catherine Mallik ${ }^{2}$, Jean-François Mangin ${ }^{12}$, Karl Mann ${ }^{3}$, Jean-Luc Martinot ${ }^{12}$, Eva Mennigen ${ }^{16}$, Fabiana Mesquita de Carvahlo ${ }^{2}$, Xavier Mignon ${ }^{21}$, Ruben Miranda ${ }^{12}$, Kathrin Müller ${ }^{16}$, Frauke Nees ${ }^{3}$, Charlotte Nymberg ${ }^{2}$, Marie-Laure Paillere ${ }^{12}$, Tomas Paus $^{14}$, Zdenka Pausova ${ }^{14}$, Jean-Baptiste Poline ${ }^{20}$, Luise Poustka ${ }^{15}$, Michael Rapp ${ }^{1}$, Gabriel Robert ${ }^{2}$, Jan Reuter ${ }^{1}$, Marcella Rietschel ${ }^{3}$, Stephan Ripke ${ }^{1}$, Trevor Robbins ${ }^{19}$, Sarah Rodehacke ${ }^{16}$, John Rogers ${ }^{24}$, Alexander Romanowski ${ }^{1}$, Barbara Ruggeri ${ }^{2}$, Christine Schmäl ${ }^{3}$, Dirk Schmidt $^{16}$, Sophia Schneider ${ }^{6}$, MarkGunter Schumann ${ }^{2}$, Florian Schubert $^{11}$, Yannick Schwartz ${ }^{20}$, Michael Smolka ${ }^{16}$, Wolfgang Sommer $^{3}$, Rainer Spanagel ${ }^{3}$, Claudia Speiser ${ }^{26}$, Tade Spranger ${ }^{23}$, Alicia Stedman $^{22}$, Sabina Steiner ${ }^{3}$, Dai Stephens ${ }^{27}$, Nicole Strache ${ }^{1}$, Andreas Ströhle ${ }^{1}$, Maren Struve ${ }^{17}$, Naresh Subramaniam ${ }^{19}$, Lauren Topper ${ }^{2}$, Henrik Walter ${ }^{1}$, Robert Whelan ${ }^{17}$, Steve Williams ${ }^{2}$, Juliana Yacubian ${ }^{6}$, 
Monica Zilbovicius ${ }^{12}$, C. Peng Wong ${ }^{2}$, Steven Lubbe $^{2}$, Lourdes Martinez-Medina ${ }^{2}$, Alinda Fernandes ${ }^{2}$, Amir Tahmasebi ${ }^{14}$

${ }^{19}$ Behavioural and Clinical Neuroscience Institute, Cambridge Univesity, Cambridge, UK; ${ }^{20}$ Commissariat àl'Energie Atomique, Paris, France; ${ }^{21}$ PERTIMM, Paris, France; ${ }^{22}$ University of Nothingem, Nothingem, UK; ${ }^{23}$ Deutsches Referenzzentrum für Ethik, Bonn, Deutchland, Germany; ${ }^{24}$ Delosis, London, UK; ${ }^{25}$ Centre Nationel de Genotypage, Paris, France; ${ }^{26} \mathrm{GABO}$ :milliarium mbH \& Co. KG, Munich, Germany; ${ }^{27}$ School of Psychiology, University of Sussex, Brighton, UK

\section{Compliance with ethical standards}

Conflict of interest TB has served as an advisor or consultant to Bristol-Myers Squibb, DesitinArzneimittel, Eli Lilly, Medice, Novartis, Pfizer, Shire, UCB, and Vifor Pharma; he has received conference attendance support, conference support, or speaking fees from Eli Lilly, Janssen McNeil, Medice, Novartis, Shire, and UCB; and he is involved in clinical trials conducted by Eli Lilly, Novartis, and Shire; the present work is unrelated to these relationships. GB has received honoraria from General Electric Healthcare for teaching on scanner programming courses and acts as a consultant for IXICO. The other authors report no biomedical financial interests or potential conflicts of interest.

Publisher's note Springer Nature remains neutral with regard to jurisdictional claims in published maps and institutional affiliations.

Open Access This article is licensed under a Creative Commons Attribution 4.0 International License, which permits use, sharing, adaptation, distribution and reproduction in any medium or format, as long as you give appropriate credit to the original author(s) and the source, provide a link to the Creative Commons license, and indicate if changes were made. The images or other third party material in this article are included in the article's Creative Commons license, unless indicated otherwise in a credit line to the material. If material is not included in the article's Creative Commons license and your intended use is not permitted by statutory regulation or exceeds the permitted use, you will need to obtain permission directly from the copyright holder. To view a copy of this license, visit http://creativecommons. org/licenses/by/4.0/.

\section{References}

1. Lesch K-P, Bengel D, Heils A, Sabol SZ, Greenberg BD, Petri S, et al. Association of anxiety-related traits with a polymorphism in the serotonin transporter gene regulatory region. Science. 1996;274:1527-31.

2. Heinz A, Higley JD, Gorey JG, Saunders RC, Jones DW, Hommer D, et al. In Vivo association between alcohol intoxication, aggression, and serotonin transporter availability in nonhuman primates. Am J Psychiatry. 1998;155:1023-8.

3. Pohjalainen T, Rinne JO, Någren K, Lehikoinen $\mathrm{P}$, Anttila K, Syvälahti EK, et al. The A1 allele of the human D2 dopamine receptor gene predicts low D2 receptor availability in healthy volunteers. Mol Psychiatry. 1998;3:256-60.

4. Stein JL, Medland SE, Vasquez AA, Hibar DP, Senstad RE, Winkler AM, et al. Identification of common variants associated with human hippocampal and intracranial volumes. Nat Genet. 2012;44:552-61.
5. Laruelle M, Gelernter J, Innis RB. D2 receptors binding potential is not affected by Taq1 polymorphism at the D2 receptor gene. Mol Psychiatry. 1998;3:261-5.

6. Egan MF, Goldberg TE, Kolachana BS, Callicott JH, Mazzanti CM, Straub RE, et al. Effect of COMT Val108/158 Met genotype on frontal lobe function and risk for schizophrenia. Proc Natl Acad Sci USA. 2001;98:6917-22.

7. Rose EJ, Donohoe G. Brain vs behavior: an effect size comparison of neuroimaging and cognitive studies of genetic risk for schizophrenia. Schizophr Bull. 2013;39:518-26.

8. Mier D, Kirsch P, Meyer-Lindenberg A. Neural substrates of pleiotropic action of genetic variation in COMT: a meta-analysis. Mol Psychiatry. 2010;15:918-27.

9. Murphy SE, Norbury R, Godlewska BR, Cowen PJ, Mannie ZM, Harmer CJ, et al. The effect of the serotonin transporter polymorphism (5-HTTLPR) on amygdala function: a meta-analysis. Mol Psychiatry. 2013;18:512-20.

10. Reimold M, Knobel A, Rapp MA, Batra A, Wiedemann K, Ströhle A, et al. Central serotonin transporter levels are associated with stress hormone response and anxiety. Psychopharmacology. 2011;213:563-72.

11. Kobiella A, Reimold M, Ulshöfer DE, Ikonomidou VN, Vollmert C, Vollstädt-Klein S, et al. How the serotonin transporter 5HTTLPR polymorphism influences amygdala function: the roles of in vivo serotonin transporter expression and amygdala structure. Transl Psychiatry. 2011;1:e37.

12. Schumann G, Loth E, Banaschewski T, Barbot A, Barker G, Büchel $\mathrm{C}$, et al. The IMAGEN study: reinforcement-related behaviour in normal brain function and psychopathology. Mol Psychiatry. 2010;15:1128-39.

13. ABCD Study. 2019. https://abcdstudy.org/.

14. French L, Gray C, Leonard G, Perron M, Pike GB, Richer L, et al. Early Cannabis use, polygenic risk score for Schizophrenia, and brain maturation in adolescence. JAMA Psychiatry. 2015;72:1002-11.

15. Nees F, Witt SH, Dinu-Biringer R, Lourdusamy A, Tzschoppe J, Vollstädt-Klein S, et al. BDNF Val66Met and reward-related brain function in adolescents: role for early alcohol consumption. Alcohol. 2015;49:103-10.

16. Ruggeri B, Nymberg C, Vuoksimaa E, Lourdusamy A, Wong CP, Carvalho FM, et al. Association of protein phosphatase PPM1G with alcohol use disorder and brain activity during behavioral control in a genome-wide methylation analysis. Am J Psychiatry. 2015;172:543-52.

17. Skol AD, Scott LJ, Abecasis GR, Boehnke M. Joint analysis is more efficient than replication-based analysis for two-stage genome-wide association studies. Nat Genet. 2006;38:209-13.

18. Whelan R, Conrod PJ, Poline J-B, Lourdusamy A, Banaschewski T, Barker GJ, et al. Adolescent impulsivity phenotypes characterized by distinct brain networks. Nat Neurosci. 2012;15:920-5.

19. Whelan R, Watts R, Orr CA, Althoff RR, Artiges E, Banaschewski $T$, et al. Neuropsychosocial profiles of current and future adolescent alcohol misusers. Nature. 2014;512:185-9.

20. Nakamura M, Shimada K, Konishi N. The role of $H R K$ gene in human cancer. Oncogene. 2009;27:S105.

21. George M, Rainey MA, Naramura M, Foster KW, Holzapfel MS, Willoughby LL, et al. Renal thrombotic microangiopathy in mice with combined deletion of endocytic recycling regulators EHD3 and EHD4. PLoS ONE. 2011. https://www.ncbi.nlm.nih.gov/ pmc/articles/PMC3052385/.

22. Khan W, Giampietro V, Banaschewski T, Barker GJ, Bokde ALW, Büchel C, et al. A multi-cohort study of ApoE $\varepsilon 4$ and Amyloid- $\beta$ effects on the hippocampus in Alzheimer's disease. $\mathbf{J}$ Alzheimers Dis. 56:1159-74, 2017. 
23. Khan W, Giampietro V, Ginestet C, Dell'Acqua F, Bouls D, Newhouse $\mathrm{S}$, et al. No differences in Hippocampal volume between carriers and non-carriers of the ApoE $\varepsilon 4$ and $\varepsilon 2$ alleles in young healthy adolescents. J Alzheimers Dis 2014;40 (Jan):37-43.

24. Hass J, Walton E, Kirsten H, Liu J, Priebe L, Wolf C, et al. A genome-wide association study suggests novel loci associated with a Schizophrenia-Related brain-based phenotype. PLoS ONE. 2013. https://www.ncbi.nlm.nih.gov/pmc/articles/PMC3689744/.

25. Hibar DP, Stein JL, Renteria ME, Arias-Vasquez A, Desrivières $\mathrm{S}$, Jahanshad N, et al. Common genetic variants influence human subcortical brain structures. Nature. 2015;520:224-9.

26. Mielenz D, Reichel M, Jia T, Quinlan EB, Stöckl T, Mettang M, et al. EFhd2/Swiprosin-1 is a common genetic determinator for sensation-seeking/low anxiety and alcohol addiction. Mol Psychiatry. 2017. https://www.nature.com/mp/journal/vaop/ncurrent/ full/mp201763a.html.

27. Desrivières S, Lourdusamy A, Tao C, Toro R, Jia T, Loth E, et al. Single nucleotide polymorphism in the neuroplastin locus associates with cortical thickness and intellectual ability in adolescents. Mol Psychiatry. 2015;20:263-74.

28. Dell'Acqua F, Khan W, Gottlieb N, Giampietro V, Ginestet C, Bouls D, et al. Tract based spatial statistic reveals no differences in white matter microstructural organization between carriers and non-carriers of the APOE $\varepsilon 4$ and $\varepsilon 2$ alleles in young healthy adolescents. J Alzheimers Dis. 2015;47:977-84.

29. Richiardi J, Altmann A, Milazzo A-C, Chang C, Chakravarty MM, Banaschewski T, et al. Correlated gene expression supports synchronous activity in brain networks. Science. 2015;348:1241-4.

30. Nemmi F, Nymberg C, Darki F, Banaschewski T, Bokde ALW, Büchel C, et al. Interaction between striatal volume and DAT1 polymorphism predicts working memory development during adolescence. Dev Cogn Neurosci. 2018;30:191-9.

31. Ruggeri B, Macare C, Stopponi S, Jia T, Carvalho FM, Robert $\mathrm{G}$, et al. Methylation of OPRL1 mediates the effect of psychosocial stress on binge drinking in adolescents. J Child Psychol Psychiatry. 2017;59:650-8.

32. Xu B, Jia T, Macare C, Banaschewski T, Bokde ALW, Bromberg $\mathrm{U}$, et al. Impact of a common genetic variation associated with putamen volume on neural mechanisms of attention-deficit/ hyperactivity disorder. J Am Acad Child Adolesc Psychiatry. 2017;56:436-444.e4.

33. Nees F, Becker S, Millenet S, Banaschewski T, Poustka L, Bokde A, et al. Brain substrates of reward processing and the $\mu$ opioid receptor: a pathway into pain? PAIN. 2017;158:212.

34. Stacey D, Lourdusamy A, Ruggeri B, Maroteaux M, Jia T, Cattrell A, et al. A translational systems biology approach in both animals and humans identifies a functionally related module of accumbal genes involved in the regulation of reward processing and binge drinking in males. J Psychiatry Neurosci Jpn. 2016;41:192-202.

35. Ojelade SA, Jia T, Rodan AR, Chenyang T, Kadrmas JL, Cattrell A, et al. Rsu1 regulates ethanol consumption in Drosophila and humans. Proc Natl Acad Sci USA. 2015;112:E4085-93.

36. Nymberg C, Banaschewski T, Bokde AL, Büchel C, Conrod P, Flor $\mathrm{H}$, et al. DRD2/ANKK1 polymorphism modulates the effect of ventral striatal activation on working memory performance. Neuropsychopharmacology. 2014;39:2357-65.

37. Nees F, Witt SH, Lourdusamy A, Vollstädt-Klein S, Steiner S, Poustka L, et al. Genetic risk for nicotine dependence in the cholinergic system and activation of the brain reward system in healthy adolescents. Neuropsychopharmacology. 2013;38:2081-9.

38. Nymberg C, Jia T, Lubbe S, Ruggeri B, Desrivieres S, Barker G, et al. Neural mechanisms of attention-deficit/hyperactivity disorder symptoms are stratified by MAOA genotype. Biol Psychiatry. 2013;74:607-14.
39. Heinrich A, Lourdusamy A, Tzschoppe J, Vollstädt-Klein S, Bühler M, Steiner S, et al. The risk variant in ODZ4 for bipolar disorder impacts on amygdala activation during reward processing. Bipolar Disord. 2013;15:440-5.

40. Stacey D, Bilbao A, Maroteaux M, Jia T, Easton AC, Longueville $\mathrm{S}$, et al. RASGRF2 regulates alcohol-induced reinforcement by influencing mesolimbic dopamine neuron activity and dopamine release. Proc Natl Acad Sci USA. 2012;109:21128-33.

41. Jia T, Macare C, Desrivières S, Gonzalez DA, Tao C, Ji X, et al. Neural basis of reward anticipation and its genetic determinants. Proc Natl Acad Sci USA. 2016;113:3879-84.

42. Peña-Oliver Y, Carvalho FM, Sanchez-Roige S, Quinlan EB, Jia $\mathrm{T}$, Walker-Tilley $\mathrm{T}$, et al. Mouse and human genetic analyses associate kalirin with ventral striatal activation during impulsivity and with alcohol misuse. Front Genet. 2016;7. https://www.ncbi.nlm.nih.gov/pmc/articles/PMC4823271/.

43. Duka T, Nikolaou K, King SL, Banaschewski T, Bokde ALW, Büchel $\mathrm{C}$, et al. GABRB1 single nucleotide polymorphism associated with altered brain responses (but not performance) during measures of impulsivity and reward sensitivity in human adolescents. Front Behav Neurosci. 2017;11. https://www.ncbi. nlm.nih.gov/pmc/articles/PMC5309221/.

44. Macare C, Ducci F, Zhang Y, Ruggeri B, Jia T, Kaakinen M, et al. A neurobiological pathway to smoking in adolescence: TTC12-ANKK1-DRD2 variants and reward response. Eur Neuropsychopharmacol. 2018;28:1103-14.

45. Baker TE, Castellanos-Ryan N, Schumann G, Cattrell A, Flor H, Nees F, et al. Modulation of orbitofrontal-striatal reward activity by dopaminergic functional polymorphisms contributes to a predisposition to alcohol misuse in early adolescence. Psychol Med. 2019;49:801-10.

46. Gonzalez DA, Jia T, Pinzón JH, Acevedo SF, Ojelade SA, Xu B, et al. The Arf6 activator Efa6/PSD3 confers regional specificity and modulates ethanol consumption in Drosophila and humans. Mol Psychiatry. 2017. https://www.nature.com/mp/journal/vaop/ ncurrent/full/mp2017112a.html.

47. White TP, Loth E, Rubia K, Krabbendam L, Whelan R, Banaschewski $\mathrm{T}$, et al. Sex differences in COMT polymorphism effects on prefrontal inhibitory control in adolescence. Neuropsychopharmacology. 2014;39:2560-9.

48. Heinrich A, Nees F, Lourdusamy A, Tzschoppe J, Meier S, Vollstädt-Klein S, et al. From gene to brain to behavior: schizophrenia-associated variation in AMBRA1 alters impulsivity-related traits. Eur J Neurosci. 2013;38:2941-5.

49. Abstract_Whelan.pdf; 2017. http://91.206.61.6/media/Abstract_ Whelan.pdf.

50. Ewald A, Becker S, Heinrich A, Banaschewski T, Poustka L, Bokde A, et al. The role of the cannabinoid receptor in adolescents' processing of facial expressions. Eur $\mathrm{J}$ Neurosci. 2016;43:98-105.

51. Loth E, Poline J-B, Thyreau B, Jia T, Tao C, Lourdusamy A, et al. Oxytocin receptor genotype modulates ventral striatal activity to social cues and response to stressful life events. Biol Psychiatry. 2014;76:367-76.

52. Dickie EW, Tahmasebi A, French L, Kovacevic N, Banaschewski T, Barker GJ, et al. Global genetic variations predict brain response to faces. PLoS Genet. 2014 https://www.ncbi. nlm.nih.gov/pmc/articles/PMC4133042/.

53. Velthorst E, Froudist-Walsh S, Stahl E, Ruderfer D, Ivanov I, Buxbaum J, et al. Genetic risk for schizophrenia and autism, social impairment and developmental pathways to psychosis. Transl Psychiatry. 2018;8. https://www.ncbi.nlm.nih.gov/pmc/a rticles/PMC6158250/.

54. Stringaris A, Vidal-Ribas Belil P, Artiges E, Lemaitre H, GollierBriant $\mathrm{F}$, Wolke $\mathrm{S}$, et al. The brain's response to reward 
anticipation and depression in adolescence: dimensionality, specificity, and longitudinal predictions in a community-based sample. Am J Psychiatry. 2015;172:1215-23.

55. Büchel C, Peters J, Banaschewski T, Bokde ALW, Bromberg U, Conrod PJ, et al. Blunted ventral striatal responses to anticipated rewards foreshadow problematic drug use in novelty-seeking adolescents. Nat Commun. 2017;8. https://www.ncbi.nlm.nih. gov/pmc/articles/PMC5321762/.

56. Müller KU, Gan G, Banaschewski T, Barker GJ, Bokde ALW, Büchel $\mathrm{C}$, et al. No differences in ventral striatum responsivity between adolescents with a positive family history of alcoholism and controls. Addict Biol. 2015;20:534-45.

57. Müller KU, Mennigen E, Ripke S, Banaschewski T, Barker GJ, Büchel $\mathrm{C}$, et al. Altered reward processing in adolescents with prenatal exposure to maternal cigarette smoking. JAMA Psychiatry. 2013;70:847-56.

58. Nees F, Vollstädt-Klein S, Fauth-Bühler M, Steiner S, Mann K, Poustka L, et al. A target sample of adolescents and reward processing: same neural and behavioral correlates engaged in common paradigms? Exp Brain Res. 2012;223:429-39.

59. Schneider S, Peters J, Bromberg U, Brassen S, Miedl SF, Banaschewski T, et al. Risk taking and the adolescent reward system: a potential common link to substance abuse. Am J Psychiatry. 2012;169:39-46.

60. Schneider S, Brassen S, Bromberg U, Banaschewski T, Conrod $\mathrm{P}$, Flor $\mathrm{H}$, et al. Maternal interpersonal affiliation is associated with adolescents' brain structure and reward processing. Transl Psychiatry. 2012;2:e182.

61. Peters J, Bromberg U, Schneider S, Brassen S, Menz M, Banaschewski $\mathrm{T}$, et al. Lower ventral striatal activation during reward anticipation in adolescent smokers. Am J Psychiatry. 2011;168: 540-9.

62. Nees F, Tzschoppe J, Patrick CJ, Vollstädt-Klein S, Steiner S, Poustka L, et al. Determinants of early alcohol use in healthy adolescents: the differential contribution of neuroimaging and psychological factors. Neuropsychopharmacology. 2012;37: 986-95.

63. Mikita N, Simonoff E, Pine DS, Goodman R, Artiges E, Banaschewski $\mathrm{T}$, et al. Disentangling the autism-anxiety overlap: fMRI of reward processing in a community-based longitudinal study. Transl Psychiatry. 2016;6:e845.

64. Jollans L, Zhipeng C, Icke I, Greene C, Kelly C, Banaschewski $\mathrm{T}$, et al. Ventral striatum connectivity during reward anticipation in adolescent smokers. Dev Neuropsychol. 2016;41:6-21.

65. Kaminski JA, Schlagenhauf F, Rapp M, Awasthi S, Ruggeri B, Deserno L, et al. Epigenetic variance in dopamine D2 receptor: a marker of IQ malleability? Transl Psychiatry 2018;8:1-11.

66. Papanastasiou E, Mouchlianitis E, Joyce DW, McGuire P, Banaschewski T, Bokde ALW, et al. Examination of the neural basis of psychoticlike experiences in adolescence during reward processing. JAMA Psychiatry. 2018;75:1043-51.

67. Castellanos-Ryan N, Struve M, Whelan R, Banaschewski T, Barker GJ, Bokde ALW, et al. Neural and cognitive correlates of the common and specific variance across externalizing problems in young adolescence. Am J Psychiatry. 2014;171: 1310-9.

68. Deng W, Rolls ET, Ji X, Robbins TW, Banaschewski T, Bokde ALW, et al. Separate neural systems for behavioral change and for emotional responses to failure during behavioral inhibition. Hum Brain Mapp. 2017;38:3527-37.

69. Bayard F, Thunell CN, Abé C, Almeida R, Banaschewski T, Barker G, et al. Distinct brain structure and behavior related to ADHD and conduct disorder traits. Mol Psychiatry. 2018. https:// doi.org/10.1038/s41380-018-0202-6. [Epub ahead of print].

70. Bourque J, Spechler PA, Potvin S, Whelan R, Banaschewski T, Bokde ALW, et al. Functional neuroimaging predictors of self- reported psychotic symptoms in adolescents. Am J Psychiatry. 2017;174:566-75.

71. Quinlan EB, Cattrell A, Jia T, Artiges E, Banaschewski T, Barker G, et al. Psychosocial stress and brain function in adolescent psychopathology. Am J Psychiatry. 2017; 174:785-94.

72. Spechler PA, Orr CA, Chaarani B, Kan K-J, Mackey S, Morton A, et al. Cannabis use in early adolescence: evidence of amygdala hypersensitivity to signals of threat. Dev Cogn Neurosci. 2015;16:63-70.

73. Lee NC, Krabbendam L, White TP, Meeter M, Consortium I, Schumann G, et al. Do you see what I see? Sex differences in the discrimination of facial emotions during adolescence. Emotion. 2013;2013:1030-40.

74. Tahmasebi AM, Artiges E, Banaschewski T, Barker GJ, Bruehl $\mathrm{R}$, Büchel $\mathrm{C}$, et al. Creating probabilistic maps of the face network in the adolescent brain: A multicentre functional MRI study. Hum Brain Mapp. 2012;33:938-57.

75. Schneider S, Peters J, Bromberg U, Brassen S, Menz MM, Miedl $\mathrm{SF}$, et al. Boys do it the right way: sex-dependent amygdala lateralization during face processing in adolescents. NeuroImage. 2011;56:1847-53.

76. Marečková K, Perrin JS, Nawaz Khan I, Lawrence C, Dickie E, McQuiggan DA, et al. Hormonal contraceptives, menstrual cycle and brain response to faces. Soc Cogn Affect Neurosci. 2014;9: 191-200.

77. Gollier-Briant F, Paillère-Martinot M-L, Lemaitre H, Miranda R, Vulser H, Goodman R, et al. Neural correlates of three types of negative life events during angry face processing in adolescents. Soc Cogn Affect Neurosci. 2016;11:1961-9.

78. Fauth-Bühler M, de Rover M, Rubia K, Garavan H, Abbott S, Clark L, et al. Brain networks subserving fixed versus performance-adjusted delay stop trials in a stop signal task. Behav Brain Res. 2012;235:89-97.

79. Stringaris A, Castellanos-Ryan N, Banaschewski T, Barker GJ, Bokde AL, Bromberg U, et al. Dimensions of manic symptoms in youth: psychosocial impairment and cognitive performance in the IMAGEN sample. J Child Psychol Psychiatry. 2014;55: 1380-9.

80. Thyreau B, Schwartz Y, Thirion B, Frouin V, Loth E, VollstädtKlein $S$, et al. Very large fMRI study using the IMAGEN database: sensitivity-specificity and population effect modeling in relation to the underlying anatomy. NeuroImage. 2012;61: 295-303.

81. Schumann G, Johann M, Frank J, Preuss U, Dahmen N, Laucht $\mathrm{M}$, et al. Systematic analysis of glutamatergic neurotransmission genes in alcohol dependence and adolescent risky drinking behavior. Arch Gen Psychiatry. 2008;65:826-38.

82. Fritsch V, Da Mota B, Loth E, Varoquaux G, Banaschewski T, Barker GJ, et al. Robust regression for large-scale neuroimaging studies. NeuroImage. 2015;111:431-41.

83. Schilling C, Kühn S, Romanowski A, Banaschewski T, Barbot A, Barker GJ, et al. Common structural correlates of trait impulsiveness and perceptual reasoning in adolescence. Hum Brain Mapp. 2013;34:374-83.

84. Schilling C, Kühn S, Paus T, Romanowski A, Banaschewski T, Barbot A, et al. Cortical thickness of superior frontal cortex predicts impulsiveness and perceptual reasoning in adolescence. Mol Psychiatry. 2013;18:624-30.

85. Ng B, Baptiste Poline J, Thirion B, Greicius M. Bootstrapped permutation test for multiresponse inference on brain behavior associations. In: Ourselin S, Alexander DC, Westin C-F, Cardoso MJ, editors. Information processing in medical imaging. Sabhal Mor Ostaig, Isle of Skye, United Kingdom: Springer; 2015. p. 12. (Lecture Notes in Computer Science; vol. 9123). https://hal.inria.fr/hal-01185206. 
86. Ortuño-Sierra J, Fonseca-Pedrero E, Aritio-Solana R, Velasco AM, Luis EC, de, Schumann G, et al. New evidence of factor structure and measurement invariance of the SDQ across five European nations. Eur Child Adolesc Psychiatry. 2015;24: 1523-34.

87. Jurk S, Kuitunen-Paul S, Kroemer NB, Artiges E, Banaschewski T, Bokde ALW, et al. Personality and substance use: psychometric evaluation and validation of the substance use risk profile scale (SURPS) in English, Irish, French, and German Adolescents. Alcohol Clin Exp Res. 2015;39:2234-48.

88. Ducci F, Kaakinen M, Pouta A, Hartikainen A-L, Veijola J, Isohanni $\mathrm{M}$, et al. TTC12-ANKK1-DRD2 and CHRNA5CHRNA3-CHRNB4 influence different pathways leading to smoking behaviour from adolescence to mid-adulthood. Biol Psychiatry. 2011;69:650-60.

89. Vulser H, Lemaitre H, Artiges E, Miranda R, Penttilä J, Struve $\mathrm{M}$, et al. Subthreshold depression and regional brain volumes in young community adolescents. J Am Acad Child Adolesc Psychiatry. 2015;54:832-40.

90. Galinowski A, Miranda R, Lemaitre H, Martinot M-LP, Artiges $\mathrm{E}$, Vulser $\mathrm{H}$, et al. Resilience and corpus callosum microstructure in adolescence. Psychol Med. 2015;45:2285-94.

91. Kühn S, Witt C, Banaschewski T, Barbot A, Barker GJ, Büchel $\mathrm{C}$, et al. From mother to child: orbitofrontal cortex gyrification and changes of drinking behaviour during adolescence. Addict Biol. 2016;21:700-8.

92. O'Leary-Barrett M, Pihl RO, Artiges E, Banaschewski T, Bokde ALW, Büchel C, et al. Personality, attentional biases towards emotional faces and symptoms of mental disorders in an adolescent sample. PLoS ONE. 2015. https://www.ncbi.nlm.nih. gov/pmc/articles/PMC4457930/.

93. Paillère Martinot M-L, Lemaitre $H$, Artiges E, Miranda R, Goodman R, Penttilä J, et al. White-matter microstructure and gray-matter volumes in adolescents with subthreshold bipolar symptoms. Mol Psychiatry. 2014;19:462-70.

94. Da Mota B, Fritsch V, Varoquaux G, Banaschewski T, Barker GJ, Bokde ALW, et al. Randomized parcellation based inference. NeuroImage. 2013; 1;89:203-15.

95. Tzschoppe J, Nees F, Banaschewski T, Barker GJ, Büchel C, Conrod PJ, et al. Aversive learning in adolescents: modulation by amygdala-prefrontal and amygdala-hippocampal connectivity and neuroticism. Neuropsychopharmacology. 2014;39: 875-84.

96. Kühn S, Lorenz R, Banaschewski T, Barker GJ, Büchel C, Conrod PJ, et al. Positive association of video game playing with left frontal cortical thickness in adolescents. PLoS ONE. 2014. https://www.ncbi.nlm.nih.gov/pmc/articles/PMC3954649/.

97. Montigny C, Castellanos-Ryan N, Whelan R, Banaschewski T, Barker GJ, Büchel C, et al. A phenotypic structure and neural correlates of compulsive behaviors in adolescents. PLOS ONE. 2013 https://www.ncbi.nlm.nih.gov/pmc/articles/PMC3828212/.

98. Kühn S, Romanowski A, Schilling C, Banaschewski T, Barbot A, Barker GJ, et al. Manual dexterity correlating with right lobule VI volume in right-handed 14-year-olds. NeuroImage. 2012;59:1615-21.

99. Mackey S, Chaarani B, Kan K-J, Spechler PA, Orr C, Banaschewski $\mathrm{T}$, et al. Brain regions related to impulsivity mediate the effects of early adversity on antisocial behavior. Biol Psychiatry. 2017;82:275-82.

100. Urrila AS, Artiges E, Massicotte J, Miranda R, Vulser H, Bézivin-Frere $\mathrm{P}$, et al. Sleep habits, academic performance, and the adolescent brain structure. Sci Rep. 2017;7. https://www. ncbi.nlm.nih.gov/pmc/articles/PMC5299428/.

101. Miller ML, Ren Y, Szutorisz H, Warren NA, Tessereau C, Egervári $\mathrm{G}$, et al. Ventral striatal regulation of CREM mediates impulsive action and drug addiction vulnerability. Mol
Psychiatry. 2017. https://www.ncbi.nlm.nih.gov/pmc/articles/ PMC5656565/.

102. Toro R, Poline J-B, Huguet G, Loth E, Frouin V, Banaschewski $\mathrm{T}$, et al. Genomic architecture of human neuroanatomical diversity. Mol Psychiatry. 2015;20:1011-6.

103. Da Mota B, Tudoran R, Costan A, Varoquaux G, Brasche G, Conrod $\mathrm{P}$, et al. Machine learning patterns for neuroimaginggenetic studies in the cloud. Front Neuroinform. 2014;8. https://www.ncbi.nlm.nih.gov/pmc/articles/PMC3986524/.

104. Shin J, Bourdon C, Bernard M, Wilson MD, Reischl E, Waldenberger $\mathrm{M}$, et al. Layered genetic control of DNA methylation and gene expression: a locus of multiple sclerosis in healthy individuals. Hum Mol Genet. 2015;24:5733-45.

105. Heinrich A, Müller KU, Banaschewski T, Barker GJ, Bokde ALW, Bromberg U, et al. Prediction of alcohol drinking in adolescents: personality-traits, behavior, brain responses, and genetic variations in the context of reward sensitivity. Biol Psychol. 2016;118:79-87.

106. Lancaster TM, Linden DE, Tansey KE, Banaschewski T, Bokde ALW, Bromberg U, et al. Polygenic risk of psychosis and ventral striatal activation during reward processing in healthy adolescents. JAMA Psychiatry. 2016;73:852-61.

107. Burt KB, Whelan R, Conrod PJ, Banaschewski T, Barker GJ, Bokde ALW, et al. Structural brain correlates of adolescent resilience. J Child Psychol Psychiatry. 2016;57:1287-96.

108. Castellanos-Ryan N, Brière FN, O'Leary-Barrett M, Banaschewski T, Bokde A, Bromberg $\mathrm{U}$, et al. The structure of psychopathology in adolescence and its common personality and cognitive correlates. J Abnorm Psychol. 2016;125:1039-52.

109. Bartholdy S, Allen K, Hodsoll J, O'Daly OG, Campbell IC, Banaschewski $\mathrm{T}$, et al. Identifying disordered eating behaviours in adolescents: how do parent and adolescent reports differ by sex and age? Eur Child Adolesc Psychiatry. 2017;26:691-701.

110. Sadaghiani S, Ng B, Altmann A, Poline J-B, Banaschewski T, Bokde ALW, et al. Overdominant effect of a CHRNA4 polymorphism on cingulo-opercular network activity and cognitive control. J Neurosci. 2017;37:9657-66.

111. Spechler PA, Allgaier N, Chaarani B, Whelan R, Watts R, Orr C, et al. The initiation of cannabis use in adolescence is predicted by sex-specific psychosocial and neurobiological features. Eur $\mathrm{J}$ Neurosci. 2019;50:2346-56.

112. Vulser H, Paillère Martinot M-L, Artiges E, Miranda R, Penttilä $\mathrm{J}$, Grimmer $\mathrm{Y}$, et al. Early variations in white matter microstructure and depression outcome in adolescents with subthreshold depression. Am J Psychiatry. 2018;175:1255-64.

113. Cury C, Glaunès JA, Toro R, Chupin M, Schumann G, Frouin V, et al. Statistical shape analysis of large datasets based on diffeomorphic iterative centroids. Front Neurosci. 2018;12. https://www.frontiersin.org/articles/10.3389/fnins.2018.00803/ full.

114. Quinlan EB, Barker ED, Luo Q, Banaschewski T, Bokde ALW, Bromberg U, et al. Peer victimization and its impact on adolescent brain development and psychopathology. Mol Psychiatry. 2018. https://doi.org/10.1038/s41380-018-0297-9. [Epub ahead of print].

115. D'Alberto N, Chaarani B, Orr CA, Spechler PA, Albaugh MD, Allgaier $\mathrm{N}$, et al. Individual differences in stop-related activity are inflated by the adaptive algorithm in the Stop Signal Task. Hum Brain Mapp. 2018;39:3263-76.

116. Huguet G, Schramm C, Douard E, Jiang L, Labbe A, Tihy F, et al. Measuring and estimating the effect sizes of copy number variants on general intelligence in community-based samples. JAMA Psychiatry. 2018;75:447-57.

117. Brislin SJ, Patrick CJ, Flor H, Nees F, Heinrich A, Drislane LE, et al. Extending the construct network of trait disinhibition to 
the neuroimaging domain: validation of a bridging scale for use in the European IMAGEN Project. Assessment. 2019;26:567-81.

118. Bogdan R, Salmeron BJ, Carey CE, Agrawal A, Calhoun VD, Garavan $\mathrm{H}$, et al. Imaging genetics and genomics in psychiatry: a critical review of progress and potential. Biol Psychiatry. 2017;82:165-75.

119. Rubia K, Smith AB, Taylor E, Brammer M. Linear age-correlated functional development of right inferior fronto-striato-cerebellar networks during response inhibition and anterior cingulate during error-related processes. Hum Brain Mapp. 2007;28:1163-77.

120. Grosbras M-H, Paus T. Brain networks involved in viewing angry hands or faces. Cereb Cortex. 2006;16:1087-96.

121. Knutson B, Westdorp A, Kaiser E, Hommer D. FMRI visualization of brain activity during a monetary incentive delay task. NeuroImage. 2000;12:20-7.

122. Charlet K, Beck A, Heinz A. The dopamine system in mediating alcohol effects in humans. In: Behavioral neurobiology of alcohol addiction. Berlin, Heidelberg: Springer; 2011. p. 461-88. (Current Topics in Behavioral Neurosciences). https://link. springer.com/chapter/10.1007/978-3-642-28720-6_130.

123. Beck A, Schlagenhauf F, Wüstenberg T, Hein J, Kienast T, Kahnt $\mathrm{T}$, et al. Ventral striatal activation during reward anticipation correlates with impulsivity in alcoholics. Biol Psychiatry. 2009;66:734-42.

124. Xuei X, Flury-Wetherill L, Almasy L, Bierut L, Tischfield J, Schuckit M, et al. HUMAN GENETIC STUDY: association analysis of genes encoding the nociceptin receptor (OPRL1) and its endogenous ligand (PNOC) with alcohol or illicit drug dependence. Addict Biol. 2008;13:80-7.

125. Kuzmin A, Bazov I, Sheedy D, Garrick T, Harper C, Bakalkin G. Expression of pronociceptin and its receptor is downregulated in the brain of human alcoholics. Brain Res. 2009;1305(Suppl): S80-5.

126. Schumann G, Coin LJ, Lourdusamy A, Charoen P, Berger KH, Stacey D, et al. Genome-wide association and genetic functional studies identify autism susceptibility candidate 2 gene (AUTS2) in the regulation of alcohol consumption. Proc Natl Acad Sci USA. 2011;108:7119-24.

127. Easton AC, Rotter A, Lourdusamy A, Desrivières S, FernándezMedarde A, Biermann T, et al. Rasgrf2 controls dopaminergic adaptations to alcohol in mice. Brain Res Bull. 2014;109:143-50.

128. Easton AC, Rotter A, Lourdusamy A, Desrivières S, FernándezMedarde A, Biermann T, et al. Rasgrf2 controls noradrenergic involvement in the acute and subchronic effects of alcohol in the brain. Psychopharmacology. 2014;231:4199-209.

129. Heinz A. Dopaminergic dysfunction in alcoholism and schizophrenia-psychopathological and behavioral correlates. Eur Psychiatry. 2002;17:9-16.

130. Luijten M, Schellekens AF, Kühn S, Machielse MWJ, Sescousse G. Disruption of reward processing in addiction: an image-based meta-analysis of functional magnetic resonance imaging studies. JAMA Psychiatry. 2017;74:387-98.

131. Peciña M, Martínez-Jauand M, Love T, Heffernan J, Montoya P, Hodgkinson C, et al. Valence-specific effects of BDNF Val66Met polymorphism on dopaminergic stress and reward processing in humans. J Neurosci. 2014;34:5874-81.

132. Benzerouk F, Gierski F, Raucher-chéné D, Ramoz N, Gorwood $\mathrm{P}$, Kaladjian A, et al. Association study between reward dependence and a functional Bdnf polymorphism in adult women offspring of alcohol-dependent probands. Psychiatr Genet. 2015;25:208-11.

133. Wojnar M, Brower KJ, Strobbe S, Ilgen M, Matsumoto H, Nowosad I, et al. Association between Val66Met Brain-Derived Neurotrophic Factor (BDNF) gene polymorphism and posttreatment relapse in alcohol dependence. Alcohol Clin Exp Res. 2009;33:693-702.
134. Pandey SC. A critical role of brain-derived neurotrophic factor in alcohol consumption. Biol Psychiatry. 2016;79:427-9.

135. Yan Q-S, Feng M-J, Yan S-E. Different expression of brainderived neurotrophic factor in the nucleus accumbens of alcoholpreferring $(\mathrm{P})$ and -nonpreferring (NP) rats. Brain Res. 2005;1035:215-8.

136. Moonat S, Sakharkar AJ, Zhang H, Pandey SC. The role of amygdaloid brain-derived neurotrophic factor, activity-regulated cytoskeleton-associated protein and dendritic spines in anxiety and alcoholism. Addict Biol. 2011;16:238-50.

137. Orrù $\mathrm{A}, \mathrm{Caffino} \mathrm{L}$, Moro $\mathrm{F}$, Cassina $\mathrm{C}$, Giannotti G, Di Clemente $\mathrm{A}$, et al. Contingent and non-contingent recreational-like exposure to ethanol alters BDNF expression and signaling in the cortico-accumbal network differently. Psychopharmacology 2016;233:3149-60.

138. Insel T, Cuthbert B, Garvey M, Heinssen R, Pine DS, Quinn K, et al. Research Domain Criteria (RDoC): toward a new classification framework for research on mental disorders. Am J Psychiatry. 2010;167:748-51.

139. Arrondo G, Segarra N, Metastasio A, Ziauddeen H, Spencer J, Reinders NR, et al. Reduction in ventral striatal activity when anticipating a reward in depression and schizophrenia: a replicated cross-diagnostic finding. Front Psychol. 2015;6. https://www.ncbi.nlm.nih.gov/pmc/articles/PMC4549553/.

140. Hägele C, Schlagenhauf F, Rapp M, Sterzer P, Beck A, Bermpohl F, et al. Dimensional psychiatry: reward dysfunction and depressive mood across psychiatric disorders. Psychopharmacology. 2015;232:331-41.

141. Koolschijn PCMP, van Haren NEM, Lensvelt-Mulders GJLM, Hulshoff Pol HE, et al. volume abnormalities in major depressive disorder: a meta-analysis of magnetic resonance imaging studies. Hum Brain Mapp. 2009;30:3719-35.

142. Carter CS, Braver TS, Barch DM, Botvinick MM, Noll D, Cohen JD. Anterior cingulate cortex, error detection, and the online monitoring of performance. Science. 1998;280:747-9.

143. Carl H, Walsh E, Eisenlohr-Moul T, Minkel J, Crowther A, Moore $\mathrm{T}$, et al. Sustained anterior cingulate cortex activation during reward processing predicts response to psychotherapy in major depressive disorder. J Affect Disord 2016;203:204-12.

144. Schlagenhauf F, Rapp MA, Huys QJM, Beck A, Wüstenberg T, Deserno L, et al. Ventral striatal prediction error signaling is associated with dopamine synthesis capacity and fluid intelligence. Hum Brain Mapp. 2013;34:1490-9.

145. Friedel E, Schlagenhauf F, Beck A, Dolan RJ, Huys QJM, Rapp MA, et al. The effects of life stress and neural learning signals on fluid intelligence. Eur Arch Psychiatry Clin Neurosci. 2015;265:35-43.

146. Hill SY, Lichenstein S, Wang S, Carter H, McDermott M. Caudate volume in offspring at ultra high risk for alcohol dependence: COMT Val158Met, DRD2, externalizing disorders, and working memory. Adv. Mol Imaging. 2013;3:43-54.

147. Richter A, Barman A, Wüstenberg T, Soch J, Schanze D, Deibele A, et al. Behavioral and neural manifestations of reward memory in carriers of low-expressing versus high-expressing genetic variants of the Dopamine D2 receptor. Front Psychol. 2017;8. https://www.ncbi.nlm.nih.gov/pmc/articles/PMC5410587/.

148. Heinz AJ, Beck A, Meyer-Lindenberg A, Sterzer P, Heinz A. Cognitive and neurobiological mechanisms of alcohol-related aggression. Nat Rev Neurosci. 2011;12:400-13.

149. Alexander GE, DeLong MR, Strick PL. Parallel organization of functionally segregated circuits linking Basal Ganglia and cortex. Annu Rev Neurosci. 1986;9:357-81.

150. Quinlan EB, Banaschewski T, Barker GJ, Bokde ALW, Bromberg U, Büchel $\mathrm{C}$, et al. Identifying biological markers for improved precision medicine in psychiatry. Mol Psychiatry. 2020;25:243-53. 


\section{Affiliations}

Lea Mascarell Maričić ${ }^{1} \cdot$ Henrik Walter $\mathbb{D}^{1} \cdot$ Annika Rosenthal $^{1} \cdot$ Stephan Ripke ${ }^{1}$ Erin Burke Quinlan $\mathbb{D}^{2}$. Tobias Banaschewski $\mathbb{1}^{3}$. Gareth J. Barker $\mathbb{1}^{4} \cdot$ Arun L. W. Bokde $^{5} \cdot$ Uli Bromberg $^{6}{ }^{6} \cdot$ Christian Büchel $^{7}$. Sylvane Desrivières $\mathbb{1}^{2} \cdot$ Herta Flor $^{7,8} \cdot$ Vincent Frouin $^{9} \cdot$ Hugh Garavan $^{10} \cdot$ Bernd Itterman $^{11}$.

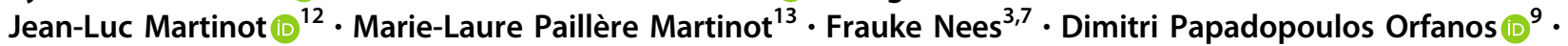
Tomáš Paus $^{14}$ - Luise Poustka ${ }^{15} \cdot$ Sarah Hohmann ${ }^{3}$ - Michael N. Smolka $\mathbb{D}^{16} \cdot$ Juliane H. Fröhner $\mathbb{D}^{16}$. Robert Whelan $\mathbb{1}^{17} \cdot$ Jakob Kaminski $\mathbb{1}^{1,18} \cdot$ Gunter Schumann $\mathbb{1}^{2} \cdot$ Andreas Heinz ${ }^{1} \cdot$ IMAGEN consortium

1 Department of Psychiatry and Psychotherapy, CharitéUniversitätsmedizin Berlin, Campus Charité Mitte, Berlin, Germany

2 Department of Social Genetic \& Developmental Psychiatry, Institute of Psychiatry, King's College London, London, UK

3 Department of Child and Adolescent Psychiatry and Psychotherapy, Central Institute of Mental Health, Medical Faculty Mannheim, Heidelberg University, Square J5, 68159 Mannheim, Germany

4 Department of Neuroimaging, Institute of Psychiatry, Psychology \& Neuroscience, King's College London, London, UK

5 Discipline of Psychiatry, School of Medicine and Trinity College Institute of Neuroscience, Trinity College Dublin, Dublin, Ireland

6 University Medical Centre Hamburg-Eppendorf, House W34, 3. OG, Martinistr. 52, 20246 Hamburg, Germany

7 Department of Cognitive and Clinical Neuroscience, Central Institute of Mental Health, Medical Faculty Mannheim, Heidelberg University, Square J5, Mannheim, Germany

8 Department of Psychology, School of Social Sciences, University of Mannheim, 68131 Mannheim, Germany

9 NeuroSpin, CEA, Université Paris-Saclay, F-91191 Gif-surYvette, France

10 Departments of Psychiatry and Psychology, University of Vermont, Burlington, VT 05405, USA
11 Physikalisch-Technische Bundesanstalt (PTB), Abbestr. 2-12, Berlin, Germany

12 Institut National de la Santé et de la Recherche Médicale, INSERM Unit 1000 "Neuroimaging\& Psychiatry", University Paris Sud, University Paris Descartes-Sorbonne Paris Cité, and Maison de Solenn, Paris, France

13 Institut National de la Santé et de la Recherche Médicale, INSERM Unit 1000 "Neuroimaging \& Psychiatry", University Paris Sud, University Paris Descartes, Sorbonne Université, and AP-HP, Department of Child and Adolescent Psychiatry, PitiéSalpêtrière Hospital, Paris, France

14 Rotman Research Institute, Baycrest and Departments of Psychology and Psychiatry, University of Toronto, Toronto, ON M6A 2E1, Canada

15 Department of Child and Adolescent Psychiatry and Psychotherapy, University Medical Centre Göttingen, vonSiebold-Str. 5, 37075 Göttingen, Germany

16 Department of Psychiatry and Neuroimaging Center, TechnischeUniversität Dresden, Dresden, Germany

17 School of Psychology and Global Brain Health Institute, Trinity College Dublin, Dublin, Ireland

18 Berlin Institute of Health, Berlin, Germany 